\title{
The Variety of Governance Structures \\ beyond Market and Hierarchy ${ }^{1)}$
}

\author{
Mark Ebers \\ WISO Faculty \\ University of Koeln \\ Albertus-Magnus-Platz \\ 50923 Koeln \\ Germany
}

Tel: +492212702458 Fax: +492214707883

email: ebers@wiso.uni-koeln.de

\author{
Leon A. G. Oerlemans \\ Department of Organisation Studies/Center for Innovation Research \\ University of Tilburg \\ Graduate School of Technology Management \\ Department of Engineering and Technology Management \\ University of Pretoria, Republic of South Africa \\ P.O. Box 90153 \\ 5000 LE Tilburg \\ The Netherlands \\ Tel: +31134663153 Fax: +31134663002 \\ E-mail: l.a.g.oerlemans@uvt.nl
}

1) Mark Ebers gratefully acknowledges that that his 2012/13 Fellowship at the Institute for Advanced Studies, Hebrew University, Jerusalem, gave him the space and time to work on the revision of this manuscript. 


\title{
The Variety of Governance Structures \\ beyond Market and Hierarchy
}

\begin{abstract}
While research has identified a variety of hybrid governance structures, it has described and sought to explain this variety from different theoretical perspectives that are not readily reconcilable. This limits our ability systematically to compare different types of hybrids and on this basis to further theoretical understanding. Results of an empirical survey of transactions in buyersupplier relations in the German construction industry provide novel insights into three distinct, widely employed types of hybrid governance structures. The study systematically compares the found hybrid governance structures and explores their rationales. As its main theoretical contribution, this study suggests that embeddedness and transaction cost arguments complement one another in explaining different and previously theoretically unspecified types of hybrid governance structures. (117 words)
\end{abstract}

Keywords: hybrid governance structures, latent class analysis, typology, embeddedness, transaction cost theory. 


\section{INTRODUCTION}

The literature has noted a bewildering spectrum of governance structures that exist besides market and hierarchy—ranging from e.g. subcontracting, alliances, joint ventures to quasi-integration—variously collectively called hybrid (Hennart, 1993; Hodgson, 2002; Makadok \& Coff, 2009; Ménard, 2004; Williamson, 1991), plural (Bradach \& Eccles, 1989; Cannon, Achrol \& Gundlach, 2000), intermediate (Kasch \& Dowling, 2008) or non-standard forms (Helper, MacDuffie \& Sabel, 2000) of governance. While there is some debate on the defining features of market and hierarchical governance structures and the different forms they can take (e.g. Hodgson, 2002; Milgrom \& Roberts, 1992; Swedberg, 2003; Zenger \& Hesterly, 1997), the literature on governance structures beyond market and hierarchy is perhaps even more diverse with regard to how it has conceptualized and measured its study object (see Bruce \& Jordan, 2007; Masten, 1996; Ménard, 2004). In the following, we speak of hybrid governance structures when referring to governance structures that are neither markets nor hierarchies, as this is the most widely applied notion.

While empirical analyses of hybrid governance structures provide rich descriptive detail about how these organizational forms are designed and operate, they are mainly based on case studies focusing on individual kinds of hybrids and have applied different dimensions for describing and analysing their study object. As a result, we know quite a bit about the diversity of hybrid forms of governance. However, as studies have examined hybrid governance structures along different dimensions, it remains difficult systematically to compare findings on the various hybrid governance structures studied, delineate how they differ from one another and typical market relations, and explicate how we can theoretically account for one type of hybrid being chosen over another or market governance (Ménard, 2012). Moreover, it makes it difficult to assess em- 
pirically across different hybrid governance structures the validity of theoretical explanations offered in the extant literature. Together, these issues have hindered theory development and impaired our ability to develop a holistic understanding of the variety of hybrid governance structures.

As hybrid governance structures constitute a significant share of all forms of governance (Hennart, 1993), it seems important better to understand and explain their make-up. We need to determine whether they can indeed be subsumed under one notion, as their classification as hybrid (or plural or intermediate) forms suggests. This would be warranted if they share important characteristics and are subject to the same explanatory logic. Or is it the case that various hybrid forms differ so much in terms of their characteristics that they constitute distinct types of governance structures which require different theoretical explanations? Then we would need to extend the threefold typology of market, hybrid and hierarchical governance structures that dominates the literature. In order to shed some light on these issues, the present study addresses the following two main research questions:

1. Which distinct hybrids prevail for governing dyadic exchange relations in the German construction industry and how do they differ from one another as well as from ideal-typical market and hierarchical relations?

2. Which factors contribute to explaining the found hybrids?

In answering these questions, the present study offers an empirically-based and theoryinformed analysis and explication of different forms of hybrid governance structures. Following Menard's (2004) suggestion that research should study the co-existence of different governance structures in the same sector, the present large $\mathrm{N}$ study systematically assesses on the basis of a configurational approach (Meyer, Tsui \& Hinings, 1993; Short, Payne \& Ketchen, 2008) the variety of governance structures that exist in the German construction industry. Based upon the 
conceptualization of governance structures proposed by the most established and well-tried theory concerned with explaining governance structures - transaction cost theory as outlined by Williamson $(1985,1991)$ — we describe the different types of governance structures that are utilized in this industry.

Results indicate that the variety of governance structures beyond market and hierarchy that exists within the German construction industry clusters around three distinct types of hybrids. First, we observe the governance structure of intermediate hybrids that fully conforms to notions forwarded in the extant literature. Second, we detect two further types of hybrid governance structures that are distinctly different from the intermediate type: safeguarded management and selective risk management. We then probe whether or not these hybrid governance structures can be explained in the same way and find that the explanatory variables emphasized by transaction cost economics do not sufficiently discriminate across the different forms of hybrid and market governance structures. We therefore suggest a theoretical argument that consistently extends received transaction cost economic explanations of hybrid governance structures by embeddedness arguments. Specifically, we outline how the embeddedness of transactions in repeated and trusted relations and industry norms affect the comparative costs of governance and can thus contribute to explaining the variety of governance structures beyond market and hierarchy in a complementary way.

This paper contributes to the literature on governance by offering an empirically based typology of hybrid governance structures that complements earlier theorizing. This approach seems fruitful, because typologies are a key tool for theory-building that propose theoretically meaningful distinctions among complex configurations of phenomena (Biggart \& Delbridge, 2004; Mantere \& Ketokivi, 2013). As its descriptive contribution, this study provides novel insights into how the variety of governance structures beyond market and hierarchy that exists within the 
German construction industry clusters around three types of hybrids that follow distinct rationales. As its main theoretical contribution, this study complements earlier research on hybrid governance structures by arguing theoretically and demonstrating empirically under which conditions and why transacting parties choose each of the three types of hybrid governance structures we find.

\section{THE VARIETY OF HYBRID GOVERNANCE STRUCTURES}

\section{AND EXTANT EXPLANATIONS}

While hybrids have been characterized in different ways, they are generally conceived as intermediate forms of governance that realize a mix of market and hierarchical governance mechanisms (Makadok \& Coff, 2009). More specifically, Williamson (1991: 283) characterizes hybrid governance structures as being “(...) located between market and hierarchy with respect to incentives, adaptability, and bureaucratic costs. As compared with the market, the hybrid sacrifices incentives in favour of superior coordination among the parts. As compared with the hierarchy, the hybrid sacrifices cooperativeness in favour of greater incentive intensity." Research has identified hybrid governance structures both between and within firms. As Menard (2004: 348) notes, external hybrids comprise "a great diversity of agreements among legally autonomous entities doing business together, mutually adjusting with little help from the price system, and sharing or exchanging technologies, capital, products, and services, but without a unified ownership" (see also Borys \& Jemison, 1989). While the literature has mainly focused on external hybrids, there are also a few studies that have analysed hybrid governance structures within firms. These internal hybrids infuse hierarchical governance forms with elements of market governance, such as transfer pricing, autonomous work-units and group-based pay systems (Foss, 2003; Zenger, 2002). 
Research has employed various labels to describe particular forms of hybrid governance structures, e.g. subcontracting (Grandori, 1997; Lai, 2000; Williamson, 2008), alliances (Albers, Wohlgezogen \& Zajac, 2013; Baker, Gibbons \& Murphy, 2008; Lin \& Lin, 2010), joint ventures (Chang, Chung \& Moon, 2013; Hennart, 1988; Pfeffer \& Nowak, 1976), selective intervention (Foss, 2003; Zenger \& Hesterly, 1997), profit centres (Powell, 1987; Walker \& Poppo, 1991), or quasi-integration (Blois, 1972; Cai, Yang \& Hu, 2009; Eccles, 1981). As this research testifies, there is quite some variation in governance structures beyond market and hierarchy (see Ménard, 2012).

Yet as Mayer and Teece (2008: 109) observe, "we do not know enough about how various forms differ (...)." One reason for this state of affairs is that almost all empirical studies selectively focus on particular forms of hybrids. Comparisons across hybrids remain rare. Moreover, when describing and analysing the focal governance structures, research has utilized a wide range of different dimensions and concepts. In their study on alliances, Mayer and Teece (2008) for instance focus on four dimensions: payment terms and incentives; administrative structure; exchange of proprietary information and technological knowledge (learning); and contingencies and dispute resolution. Other studies on alliances emphasize issues of cooperation and control (e.g. Reuer \& Ariño, 2007; White \& Lui, 2005), while Casciaro (2003) focuses on ownership by comparing equity and non-equity alliances. In further contrast, Borys and Jemison (1989) identify as four key issues that in their view form the core of a theory of hybrid alliance arrangements: breadth of purpose, boundary determination, value creation, and stability mechanisms. This account of the diversity in dimensionalizing hybrid governance arrangements could easily be extended, as it equally pertains to other forms of hybrid governance than alliances (see e.g. Buvik, 2002; Noorderhaven, 1995; Zenger, 2002). 
As a consequence of this variety of conceptualizations, it remains very difficult to compare, aggregate, and generalize about findings across studies on the same as well as across supposedly different forms of hybrids. It thus remains unclear to what extent the forms identified in the literature indeed differ substantively and not only in name. Moreover, theory development is impeded, as scholars cannot directly assess explanations suggested for hybrid governance structures. As a result, "efforts for capturing the specificity of these arrangements within a coherent analytical framework remain underdeveloped" (Ménard, 2012: 1067) so that the literature on hybrid governance structures still lacks conceptual and theoretical integration of its findings (Jolink \& Niesten, 2012). In order to achieve such comparative assessment and establish under which conditions various types of hybrid governance structures prevail, research needs to analyse a larger number of governance structures along the same dimensions of governance exploring the same possible explanatory variables in a large $\mathrm{N}$ setting. The present paper is among the first to present such an endeavour.

\section{Extant Explanations of Hybrid Governance Structures}

Various theories have been applied to explaining governance structures in general and hybrids in particular (see Cropper, Ebers, Huxham \& Ring, 2008; Jolink \& Niesten, 2012; Parmigiani \& Rivera-Santos, 2011). Two main sets of theoretical perspectives seeking to explain hybrid governance structures stand out and together dominate the literature: institutional economics and dependence/embeddedness perspectives.

Institutional economics theories explain hybrid governance structures mainly on the basis of cost efficiency considerations. From an institutional economics perspective, firms employ hybrid governance structures when it is comparatively more cost efficient than governing their transactions in market or hierarchical structures, due to efficient investments (driven by incom- 
plete contracting and the incentives of ownership), appropriation concerns (mainly driven by specific investments), uncertainty (posing risks of opportunism and need for adaptation), and/or coordination problems (that arise e.g. from misaligned incentives) (Gibbons, 2005). Rather than modelling hybrid governance structures in their own right, institutional economics theories conceptualize hybrid governance structures as some mix of market and hierarchical governance mechanisms (e.g. Hennart, 1993) and emphasize the same explanatory variables as for explaining hierarchical and market governance when seeking to explain hybrid governance structures (Buvik, 2002; Gibbons, 2005).

To the best of our knowledge, Menard's (1996) empirical study of the French poultry industry is the only one that has so far in a systematic way analysed and explicated from an institutional economics perspective different forms of hybrid governance structures to be found in one industry. He finds that hybrid governance structures are chosen because partners can gain from mutual dependence and coordination, which requires interdependent investments, but need to control the risks of opportunism. Ménard (1996) observes that different forms of hybrids of similar long-term efficiency co-exist in this industry realizing different levels of integration and mechanisms of control: a decentralized structure, a cooperative arrangement, and one that is closer to an integrated firm. He argues that the core explanatory variables emphasized by transaction cost economics cannot fully explain these hybrid structures. He shows that, in addition, the institutional rules and accepted roles of industry actors importantly shape hybrid governance design.

A second set of theoretical perspectives traces hybrid governance structures back to the dependence of organizations on and the interaction with a broader social structure. In different ways, resource dependence theory (Pfeffer \& Salancik, 2003), institutional theory (Greenwood, Oliver, Sahlin-Andersson \& Suddaby, 2007), and social network perspectives (Powell, 1990) emphasize hybrid governance structures as means by which organizations can effectively respond 
to constraints and opportunities emanating from the relations with other organizations or stakeholders in which they are embedded. Pfeffer and Nowak (1976), for instance, show that joint ventures are a form of inter-organizational linkage that organizations establish in order to manage inter-organizational interdependence, both competitive and symbiotic, that results from resource dependencies. Task characteristics and the uncertainty of resource access constitute important antecedents of how exactly firms deal with the resulting resource dependencies (Grandori, 1997). Institutional theorists submit that hybrid governance forms can be a response to coercive, normative or mimetic forces that drive organizations to comply with ways of organizing that are established, legitimate or taken-for-granted within a particular domain. In this vein, Garcia-Pont and Nohria (2002) for example demonstrate that the likelihood of an alliance between any two automobile firms depends on the local density of alliances among the members of their strategic groups, as firms closely observe and imitate the strategic behaviour of firms that occupy the same strategic niche. Uzzi's (1996) research highlights the comparative advantages of hybrid governance systems built on inter-firm networks. He argues theoretically and shows empirically that firms' embeddedness in social networks creates an exchange system providing unique opportunities relative to markets. Firms organized in networks, up to a tipping point of embeddedness, have higher survival chances than do firms which maintain arm's-length market relationships. Uzzi reasons that this is because embedded firms enjoy benefits of economies of time, integrative agreements, Pareto improvements in allocative efficiency and complex adaptation (Uzzi, 1997) as well as lower financing cost (Uzzi, 1999).

All of these theoretical arguments have received empirical support in particular empirical settings. However, for two main reasons it remains difficult comparatively to assess the respective theoretical contributions and to consolidate the findings. First, scholars have tended to apply particular theories to particular forms of hybrids. Research on alliances and joint ventures, for 
example, often utilizes transaction cost economics or resource-based theories, while franchising predominantly has been studied from an agency theory perspective. Thus, it remains difficult to tell to what extent particular theoretical arguments apply across different forms of hybrids. Second, some forms of hybrids have been studied much more widely than others. Studies of alliances and joint ventures clearly dominate the literature, while other hybrid forms, such as consortia, have received much less attention in the literature (Parmigiani \& Rivera-Santos, 2011). Therefore, our understanding of hybrid governance forms may be biased by the forms that have been studied.

In order to be able to mitigate the limitations of our understanding of hybrid governance forms that are due to the above noted fragmentation and divergence of both the extant conceptualizations and explanations of hybrids, it seems fruitful to compare different forms of hybrid governance structures applying the same analytical framework.

\section{CONCEPTUAL AND THEORETICAL FOUNDATIONS OF THE PRESENT STUDY}

As it is the most ambitious, parsimonious and widely applied body of theory for explaining governance structures and, more importantly, a theory that has received significant empirical support (Crook, Combs, Ketchen \& Aguinis, 2013; Oliver \& Ebers, 1998; Rindfleisch et al., 2010), we use institutional economics theory, in particular transactions cost economics, as our theoretical blueprint for defining the dimensions in which hybrid governance structures can vary. On this basis, we seek to identify empirically the different types of hybrid governance structures that exist in dyadic exchanges in the German construction industry. When exploring how the different hybrid forms that we find may be explained, we consider institutional economics explanations as a point of departure and baseline model, yet we shall show that it is possible, necessary and pro- 
ductive to complement these explanations in a theoretically consistent way with arguments from a second main theoretical tradition in the field: the embeddedness perspective.

\section{Conceptualization of Governance Structures}

In line with the wider institutional economics literature (e.g.Makadok \& Coff, 2009; Ménard, 2004; Milgrom \& Roberts, 1992), transaction cost theory emphasizes four dimensions in which governance structures vary: (1) ownership autonomy, (2) incentive intensity, (3) administrative controls, (4) and adaptation (Williamson, 1985, 1991). In each of these dimensions of governance structures, individual governance mechanisms combine to govern actor behaviour in economic exchange. A governance structure is, therefore, a specific configuration of governance mechanisms that co-ordinates and controls economic transactions (Hennart, 1993). Governance mechanisms include, for example, decision-making procedures, residual rights of control, contractual guarantees, contractual adaptation clauses, different pricing schemes, personal monitoring, formal rules and regulations, and procedures for conflict resolution (Dekker, 2004; Williamson, 1985). The theory argues that these governance mechanisms combine in complementary ways (Foss, 2003; Zenger, 2002) thus forming three generic types of governance structures: market, intermediate hybrid, and hierarchy. Table 1 below summarizes the ideal-typical characteristics of these three governance structures in the four dimensions of governance as described by transaction cost economics (see Ménard, 1996; Williamson, 1985, 1991).

Insert Table 1 about here

According to transaction cost theory, the transition from market, through intermediate hybrids, to hierarchical governance structures is marked by a reduction in ownership autonomy, by gradually decreasing reliance on high-powered incentive regimes, an increase in the use of mechanisms that 
implement behavioural constraints on exchange partners by means of administrative controls, and a gradual decrease of autonomous adaptation and an increased reliance on residual decisionrights. While hybrids may realize different parameter values in the four dimensions of governance, transaction cost theory thus suggests that these are highly correlated and therefore tend to move together: A greater (lesser) intensity of governance in one dimension is accompanied by a greater (or lesser) intensity in the others.

\section{Explanations of Hybrid Governance Structures: Extensions of a Base-line Model}

As we utilize institutional economics', specifically transaction cost theory's conceptualization of governance structures, we also include in our considerations the explanation of hybrid governance structures offered by the theory as a base-line argument. In a nutshell, transaction cost theory proposes that as asset specificity and behavioural uncertainty increase, market governance is replaced by hybrid and ultimately hierarchical governance structures. The theory contends that hybrid governance structures prevail when bilateral dependency between the transacting parties is strong enough to require close coordination and adaption, yet not strong enough to induce full hierarchical integration (Williamson, 1991). Empirical research has produced convincing evidence for transaction cost theory explanations of governance choice in general (Crook et al., 2013; Geyskens, Steenkamp \& Kumar, 2006; Rindfleisch et al., 2010) and of intermediate hybrid governance structures in particular, e.g. with regard to, among others, buyer-supplier relations, alliances, joint ventures, consortia, partnerships, franchising, and inter-organizational networks (see for instance Hoetker \& Mellewigt, 2009; Masten, 1996; Ménard, 2004, 2012; Oerlemans \& Meeus, 2001; White \& Lui, 2005).

However, some scholars suggest that standard transaction cost explanations need to be extended in order to provide a more complete account of governance choice (e.g. Crook et al., 2013; 
Grandori, 1997; Hoetker \& Mellewigt, 2009; Makadok \& Coff, 2009; Ménard, 1996). Grandori (1997) as well as Makadok and Coff (2009), for example, submit that governance mechanisms can combine in more ways than suggested by transaction cost theory. As was indicated above, Menard's (1996) study of governance structures in the French poultry industry empirically confirms this notion. Helper, MacDuffie and Sabel (2000) in their study of supplier relations in the automobile industry also discover governance structures that seem incompatible with the traditional transaction cost theory typology.

The transaction cost economic explanation of governance structures has been challenged on the grounds that it paints an under-socialized view of economic action that disallows any impact of social relations and the wider social structure (Granovetter, 1985). A number of scholars have therefore suggested that to understand fully the governance of transaction relationships, one has to direct greater attention to how governance arrangements are embedded in particular social relations, on the one hand, and the overall institutional contexts on the other (e.g. Dacin, Ventresca \& Beal, 1999; Ghoshal \& Moran, 1996; Granovetter, 1985; Jones, Hesterly \& Borgatti, 1997; Uzzi, 1997; Wathne \& Heide, 2004). Relational embeddedness “describes the personal relationships people have developed with each other through a history of interactions..." (Nahapiet \& Ghoshal, 1998: 244). The literature has identified a number of key facets of relational embeddedness, including interpersonal trust, continued collaboration, and reputation (Carson, Madhok \& Wu, 2006). It has been shown that relational embeddedness can mitigate transaction hazards, foster efficient exchange and affects the stability of inter-organizational relations (Dyer \& Singh, 1998; Macaulay, 1963; Polidoro, Ahuja \& Mitchell, 2011). Institutional embeddedness has been defined "as the nesting of economic and strategic activity within an institutional environment. The institutional environment of firms and markets refers to the social and normative context surrounding them, in particular, those external influences that define socially acceptable 
economic behavior." (Oliver, 1996: 164) Accordingly, industry norms have been identified as an important element of the institutional context in which the parties to a transaction are embedded (Ménard, 1996; Oliver, 1996). They pertain to implicit or explicit taken-for-granted rules about how exchange takes place in an industry and thus guide exchange behaviours to some extent. Only few studies have examined the impact of institutional embeddedness on governance structures, however (e.g. Oxley, 1999).

In the following, we specify how transaction cost and embeddedness arguments can be consistently combined for explaining the choice of governance structure. Specifically, we outline how both relational and institutional embeddedness affect the main dimensions of governance design in general, and of hybrid governance in particular, by way of their implications for transaction costs (contracting, monitoring, enforcement and adaptation costs). In line with the extant conceptualizations of relational and institutional embeddedness in the literature, we focus on frequency of past collaboration, trust, and prevalence of industry norms as different facets of embeddedness. In addition, we explore whether and to what extent other transaction attributes than those emphasized by standard transaction cost theory may be conducive to explaining hybrid governance structures, scrutinizing transaction attributes of transaction volume, transaction duration, and task complexity. We focus on these variables as possible drivers of hybrid governance structures for two main reasons. First, they have received some support in earlier and related literature, yet have neither been tested together nor with regard to a broader range of different types of hybrid governance structures. Second, the concepts are broadly compatible with the core transaction cost reasoning. They thus bear the potential consistently to extend the theory's explanation of the choice of governance structures. In this way, we seek to contribute to theory building on hybrid governance structures and provide a theoretical basis for exploring empirically why transaction parties adopt which forms of hybrid governance structures. 


\section{How facets of embeddedness impact transaction costs and hybrid governance choice.}

Past collaboration will reduce contracting costs, as the parties to a transaction can use their earlier agreements as a template for contractual language and clauses (Kalnins \& Mayer, 2004) and are more knowledgeable about each other's capabilities and reliability (Polidoro et al., 2011). It has been shown that by reducing expectations of opportunistic behaviour (Mayer \& Argyres, 2004; Poppo \& Zenger, 2002; Poppo, Zhou \& Ryu, 2008), past collaboration lowers perceived need for monitoring and protective safeguards (Gulati, 1995; Gulati \& Singh, 1998; Parkhe, 1993), thus lowering monitoring and enforcement costs. Moreover, as transaction partners over time learn to work together (Mayer \& Argyres, 2004), establish common understandings as well as transactional norms (Uzzi, 1997), there is also less need for extensive formal adaptation, administrative control, and conflict resolution mechanisms (Reuer \& Ariño, 2007; Zollo, Reuer \& Singh, 2002) so that adaptation costs will decrease with the length of a relationship.

Trust entails the expectation that a counter party will not engage in opportunistic behaviour, even when faced with incentives to behave opportunistically and irrespective of the ability to monitor or control that party (Judge \& Dooley, 2006; Schoorman, Mayer \& Davis, 2007). When a buyer trusts a supplier, s/he will feel less need to devise extensive administrative controls and protective contractual safeguards (Klein Woolthuis, Hillebrand \& Nooteboom, 2005; McEvily, Perrone \& Zaheer, 2003). A buyer can thus economize on contracting, monitoring and enforcement costs. Moreover, as trust induces reciprocal behaviour, it encourages the exchange partners to generate coordinated and cooperative responses to unforeseen disturbances (Dyer \& Chu, 2003). These responses facilitate adaptation, lower adaptation costs and in this way also impact governance choice.

Industry norms define acceptable behaviours, appropriate practices, and standards for technical performance that are widely established in a given institutional field, i.e. a particular 
trade, market segment or region (Bresnen, Edelman, Newell, Scarbrough \& Swan, 2003; Oliver, 1996). Industry norms have emerged over time within and among the trades and professions in everyday business interactions. Kadefors (2005), for example, shows how an intuitive cost-based norm of fair pricing shapes interaction in construction projects. Industry norms affect governance choice (Oxley, 1999), because they comprise binding expectations for appropriate business conduct and performance that provide incentives to conform because of possible social sanctioning (Coleman, 1990). They thus reduce the need for administrative controls and safeguards which allows transacting parties to economize on monitoring and enforcement costs. As industry norms provide accepted standards and procedures, transacting parties can draw on these norms in negotiating and formulating their contract. This reduces contracting costs. They also reduce monitoring costs, as transacting parties can avoid costly haggling over standards for conduct, performance and the verification of performance. Industry norms furthermore support flexible adjustments to unforeseen changes in exchange conditions (Jones et al., 1997; Ménard, 1996). Moreover, research has shown that industry norms create a convergence of expectations and common identity that help to coordinate interdependent activities and thus foster adaptation (Dyer \& Nobeoka, 2000). As a consequence, transacting parties can economize on adaptation costs when their transaction is embedded in industry norms.

In sum, as they influence the transaction costs, we expect that these three embeddedness variables will affect the relative efficiency of hybrid governance structures and may thus be conducive to explaining particular forms of hybrid governance structures. 


\section{How supplementary transaction attributes impact transaction costs and hybrid governance}

\section{choice.}

Transaction cost theory posits that asset specificity, uncertainty and, to a lesser extent, transaction frequency represent the crucial transaction attributes along which governance structures will align. However, the wider organizational literature has identified a number of other transactionand task-related attributes that are consequential for organization design. In the following, we focus on three such attributes and outline how they affect transaction costs, and subsequently choice of governance: transaction volume, transaction duration, and task complexity.

Monitoring costs will increase with transaction volume and duration, as more elements of a transaction need to be inspected over a longer period of time (White, 2005). Transaction volume and duration will further impact choice of governance structure, because the risks associated with a particular transaction will be greater for larger transactions that bind buyer and supplier for a longer time, affecting the perceived need for safeguards and thus contracting and enforcement costs (Dyer, 1997; Ménard, 1996). With increasing volume and duration of a transaction, it also becomes more likely that adaptations are required (Reuer \& Zollo, 2000), which has repercussions for adaptation costs and thus governance choice (Gulati, Lawrence \& Puranam, 2005).

Task complexity refers to the variety of procedures and technologies employed in a task that impacts the requirement for exact, timely and substantive coordination of different actors who contribute to performing the transaction. Task complexity has governance choice implications, as contracting costs will increase with the complexity of the tasks that are covered in the contract. Moreover, it is more costly to monitor and control complex tasks than simple ones (White \& Lui, 2005). More complex tasks furthermore provide greater possibilities for shirking due to measurement problems and are thus associated with higher enforcement costs, as it becomes more difficult to determine the relative contribution of the various inputs to output (Mayer 
\& Nickerson, 2005). Finally, task complexity enhances the adaptation requirements a governance structure has to cope with over time and thus adaptation costs, as more parameters can change than in simple tasks.

In sum, as they influence transaction costs, we empirically explore in the following whether these three transaction and task attributes, together with the embeddedness variables discussed earlier, complement the standard transaction cost theory variables in explaining the choice of hybrid governance form.

\section{METHOD}

\section{Sample and Data Collection}

The construction industry for several reasons is a particularly appropriate setting for examining hybrid governance structures. It comprises a great variety of governance structures and has long experience with different forms of governance (Eccles, 1981; González-Díaz, Arruñada \& Fernández, 2000; Lui \& Ngo, 2005; Winch, 2001). It is not known for its institutional and technological innovativeness and experimentation but rather follows long-standing traditions of how it organizes and manages intra- and inter-organizational construction projects. The construction industry thus provides a very conservative test bed for our research, as it seems much less likely that one should find exotic, untried governance structures in the construction industry than in younger, more innovative sectors such as software, electronics, or the creative industries. Furthermore and on a more general level, a one-industry research design has the advantage that between-industry variation is excluded as a source of explanation.

We invited the entire population of German construction corporations with more than 1000 employees (a total of 55 firms) to participate in the study. We focused on these large corporations, as they operate as general contractors that regularly utilize a variety of governance struc- 
tures for their transactions. Large general contractors employ their own staff for particular tasks, subcontract other construction activities and also frequently engage in consortia, alliances, and other hybrid governance forms (Costantino \& Pietroforte, 2002; White \& Lui, 2005). These construction corporations thus regularly choose which governance structure they will use for which particular transaction. Top managers from 17 of these firms agreed that their organization would participate in the study, yielding a firm-level response rate of $31 \%$.

Within these corporations, production projects are executed by regional business units operating as general contractors that bear profit and loss responsibility. To generate variance with regard to our study variables, we collected data within each corporation from at least two regional units on at least two projects per regional unit that differed in the nature of the respective construction activity. Our sample thus includes a broad range of 102 construction projects that were carried out within 52 regional organizational units throughout Germany. While a convenience sample, a comparison with industry statistics (Bauindustrie, 2009) shows that the composition of our sample is representative of the overall structure of the German construction industry in terms of construction market segments (commercial building, residential building, public works, underground construction, construction of roads, bridges and tunnels, etc.).

Within any given construction project, the different transactions involved are usually organized in different governance structures. Basic and detail engineering, for instance, may be conducted in-house by the general contractor; the provision of building materials may be organized in open bidding processes, i.e. as pure market transactions; while the general contractor may choose to conduct specialized construction jobs in some form of hybrid governance structure. Within the regional units we collected data on 223 such transactions within different projects. Both the projects and the focal transactions were selected by the respondents, yet they had to be different in kind and with different suppliers. On average, our sample contains 6 projects per cor- 
poration, 2 projects per regional unit, and 2 individual buyer-supplier transactions per construction project.

In order to ensure the validity of our data, we followed earlier research (Cannon \& Perreault Jr, 1999; John \& Weitz, 1988; White, 2005) and relied on the most knowledgeable key informants who by virtue of their position were best informed about the matters studied. The respondents were project managers responsible for designing and managing the buyer-supplier transactions in the projects on which they reported, and who were held accountable for project outcomes. As Lui and Ngo (2004: 473) point out when legitimating the key respondent method for their own survey in the construction industry, this choice of key informant is warranted, because “... the project manager $[\ldots]$ is the only person who interacts with the building contractor on a day-to-day basis and knows the full details of the cooperation process. There is only one project manager on a construction project...”. John and Reve (1982) found that key informants from different firms within marketing channel dyads could reliably and validly report about the structural form of the relationship. However, our use of the general contractor's project manager as key informant may represent a bias towards the perspective of the buyer. Yet findings by Heide and John (1990) indicate that buyers have reliable knowledge of the supplier and their market and that buyers' and suppliers' perceptions of the degree to which suppliers' employed specific assets strongly and significantly correlate. For about half of the cases, managers at the corporate level approached the regional managers to name project managers and arrange the interviews; for the other half the researchers did. We asked the respondents to report on nearly or recently completed projects and transactions they managed for which they had responsibility for the whole or large parts of the project (and thus a strong interest in, and knowledge of, project design and performance). Furthermore, the projects and transactions should reflect the normal course of events rather than exceptional circumstances. Specifically, we asked respondents to report on transac- 
tions within projects that were typical in terms of project size, duration, operational challenges and problems as well as project performance. In all, the sample contains a mix of projects and transactions that are typical of the industry population in terms of market segments and randomly distributed with regard to size, duration, and perceived success in terms of cost, quality, timeliness and other criteria (for details see Appendix 1 and Table 2).

We used pre-tests of the survey in the field to construct valid items and reliable scales that avoid ambiguity and vagueness. The final questionnaire was personally administered to the respondents to ensure their commitment. Respondents confirmed that they were well-informed about the issues surveyed and thus felt confident that they could accurately answer the questions posed. We adopted a number of procedural remedies to reduce possible common-method biases (Podsakoff, MacKenzie, Jeong-Yeon \& Podsakoff, 2003). We assured respondents of the anonymity of their responses, asked them to answer the questions as honestly as possible, and emphasized that there is no right or wrong answers. In the questionnaire, we proximally and methodologically separated the measures of the predictor and criterion variables. To assess possible common method variance problems, we applied the one-factor test suggested by Podsakoff and Organ (1986). An exploratory factor analysis of all variables yielded 12 factors explaining 68\% of the variance. This result suggests that common method variance is unlikely to be a serious issue.

\section{Measures}

Governance structures. We measure governance structures in the four dimensions advocated by transaction cost theory based on pertinent governance mechanisms. (1) We measure ownership autonomy on the basis of the management and control decision-rights that the parties to the exchange possess over their resources (Fama and Jensen (1983). (2) We measure incentive intensity 
on the basis of two dimensions. Our first measure captures the pricing scheme applied in the exchange relation. Input-oriented pricing schemes pay for effort and have only weak incentive intensity; output-oriented pricing schemes pay for performance and thus imply high incentive intensity (Ouchi, 1979). Drawing on Mesquita and Brush (2008), Argyres et al. (2007) and Luo (2002), our second incentive measure captures the intensity of contractual guarantees agreed for the exchange. Contractual guarantees provide incentives for executing a transaction as agreed between the parties. If one party does not fulfil its contractual obligations, the other party has a right to be compensated by the agreed guarantee, and thus has an incentive to perform as contractually agreed. (3) Administrative controls help to manage the (inter-)dependencies that exist between transacting parties. They establish rules of conduct and provide and structure information that then guides behaviour. Following Hoetker and Mellewigt (2009), our measure of administrative controls includes a number of instruments. Specifically, we measure the extent to which the parties control the transaction by means of plans and budgets, performance indices, screening procedures, and formal reports. As Hoetker and Mellewigt (2009), we use the average of these administrative control mechanisms as our measure of administrative controls. (4) We employ two measures of adaptation. One captures the extent to which one or both parties to the transaction hold residual decision-rights with regard to adaptations to their transaction relationship (Jensen \& Meckling, 1976). The second measure reflects the degree of detail in which four contractually specified mechanisms regulate the adaptation of the transaction to changing circumstances (Luo, 2002).

Transaction attributes. As a baseline argument, we include the two main explanatory variables for governance choice emphasized by transaction cost economics, specific investments and uncertainty. Additionally and following Nooteboom et al. (1997), we measure the volume of specif- 
ic investments with regard to four types of specific investments distinguished by transaction cost theory, namely dedicated assets, relation-specific investments, human capital investments, and customer-specific investments. Our measure of uncertainty contains various items that capture the difficulty of defining ex ante and verifying ex post the goods and services for which exchange parties are contracting (Bensaou \& Venkatraman, 1995; Mayer \& Salomon, 2006). Building on and extending the measures of Anderson and Dekker (2005), we use nine survey questions as indicators of this latent construct. Five items relate to the difficulty of defining at the time of contracting the exact specifications of the good or service to be exchanged and of the resources, technologies, and processes required for the provision of the good or service. The other four items concern the difficulty of observing and verifying the quality of the good or service provided.

Transaction volume is a monetary measure of the size of the transaction. Project duration indicates the time span in months during which the construction project was performed. Task complexity on the basis of three items measures the extent to which the transaction involves different capabilities, processes, or technologies that combine in multiple ways and require coordination among multiple actors.

Embeddedness variables. Past collaboration measures how often a firm had collaborated with the supplier in the past. Trust captures to what extent the buyer expected the supplier not to act opportunistically. Industry norms refer to institutionalized expectations about appropriate behaviour that are prevalent in, and can vary across, trades, industry segments and regions. Finally, we also use nominal data on the object of the transaction, i.e. the nature of the good or service provided by the supplier. 
Controls. To validate our multi-dimensional measures of governance structures, we measure whether buyer and supplier belong to the same firm. In order to assess the extent to which particular governance structures are perceived to be more or less successful, we measure in several dimensions that pertain to transaction cost theory the satisfaction of the buyer with the governance of the transaction.

Details of the various measurement items, scales, and respective reliability statistics are presented in the Appendix. For our analyses, we used standardized measures of all variables.

\section{Analytical Approach}

To answer our first research question, we apply a configurational approach (Meyer et al., 1993; Short et al., 2008), as it is particularly suited for the analysis of governance structures. Configurational approaches identify groups of objects, in this case governance mechanisms, that resemble each other along important dimensions and explain the prevalence of configurations on the basis of their fit within a particular context (Short et al., 2008). Accordingly, in this study we seek to identify commonly occurring configurations of governance mechanisms (i.e. governance structures) in the four dimensions of governance and explore contextual conditions under which they prevail.

We employ a statistical model that is new to configurational analysis for large datasets, latent class analysis (Vermunt \& Magidson, 2003), to probe whether the governance mechanisms indeed systematically align such that they form distinct governance structures. The primary statistical method that earlier configurational research used to derive groupings was cluster analysis (Short et al., 2008). We chose latent class analysis, because it provides a comparatively more reliable estimation of configurations based on goodness of fit indices. Latent class analysis is a statistical method for finding subtypes of related cases (latent classes) from multivariate numeric or 
categorical data on the basis of a maximum likelihood estimation (Hagenaars \& McCutcheon, 2002). In latent class analysis, a ML-algorithm classifies cases into clusters based upon membership probabilities estimated from a parametric model. The procedure seeks to identify the smallest number of latent (unobservable) classes that is sufficient to account for the relationships among the manifest (observed) variables. The latent variable is to explain all the relationships among the manifest variables of its class. The analysis begins by fitting a baseline model for but one latent class. If this one-class solution does not fit the data well, the analysis incrementally adds latent classes to the model until the model fit is adequate. Model fit is determined on the basis of a Log Likelihood (LL) criterion, in this case the Bayesian Information Criterion (BIC). In short, the BIC provides information about the explanatory power of a model relative to the number of parameters employed. The lower the BIC, the better the fit of the model (Magidson \& Vermunt, 2004). Besides the BIC, the $\mathrm{p}$-value ( $\mathrm{p}>0.05$, indicating adequate fit) and the number of parameters used (fewest number indicating parsimony) determine model selection.

To answer our second research question, we employ multi-nominal logistic regression analysis to predict membership in the found types of governance structures. This test determines which explanatory variables significantly discriminate among the found governance structures. We test by means of Scheffé tests (analysis of variance) whether the explanatory variables account for significant differences among the governance structures.

\section{RESULTS}

We present the results of our analyses in two sections that portray the findings for our two main research questions. First, we describe the variety of types of governance structures that we find to prevail in the German construction industry and their distinctive features. Second, we discuss to what extent the transaction, task and embeddedness attributes we highlighted in the theory section 
can help to explain when hybrid governance structures will be adopted. Since market governance can be regarded the default option for a transaction (Williamson, 1985), we mainly compare and seek to explain the three hybrid governance structures we identified in relation to this governance structure. Subsequently, we however also investigate why one hybrid type may be chosen over the other.

Table 2 below presents the means and standard deviations of the studied variables as well as their correlations.

Table 2 about here

\section{Types of Governance Structures}

Table 3 presents the results of our latent class analysis. The table shows the cluster means for the predictor variables of the latent classes ${ }^{1}$. The means serve to typify the configurations of governance mechanisms we found. The individual cases forming a latent class will display some variation around the means in the values of their respective latent class predictor variables. We controlled for possible company effects. Overall, we found no significant company effects.

Table 3 about here

Results show that a 5 classes solution provides the best model fit (BIC: $3257 ; \mathrm{p}=0.11$; classification error: 4\%; standard R-squared: 0.92). The latent class analysis reveals a number of configurations of governance mechanisms that exactly conform to the ideal-typical governance structures of market (configuration 1) and hierarchy (configuration 5) as outlined in a previous section of

\footnotetext{
${ }^{1}$ As a robustness test, we also calculated cluster medians which, however, produce the same cluster characteristics.
} 
this paper. ${ }^{2}$ This result thus supports the validity of the underlying measurement dimensions of governance structures.

For market governance, we find comparatively low cluster centre values for ownership autonomy indicating that the decision-rights are held by the supplier. This governance structure has strong incentive intensity due to output-oriented pricing and highly specified contractual guarantees. We observe no extensive use of administrative controls, a high degree of autonomous adaptation rights in the hands of the supplier, and some degree of regulations supporting contractual adaptation of transactions to changed circumstances. This governance structure we found to be used, for example, for transactions concerning brick laying in a supermarket building, dry walling work in an office building, and shell construction for a commercial building.

The hierarchy configuration displays almost the opposite characteristics: The values for ownership autonomy are the highest of all clusters. We observe the comparatively lowest level of incentive intensity, with few contractual guarantees and a prevalence of input-oriented pricing. Extensive administrative controls are in place. With regard to adaptation, we find the typical constellation for hierarchical employment relations: Contractual clauses regulating adaptation between the parties are largely absent; instead, the parties engage in coordinated adaptation, as indicated by a medium value for the distribution of decision-making rights with regard to autonomous or coordinated adaptation. The classification result is independently descriptively validated by the fact that $100 \%$ of the cases subjected to hierarchical governance concerned transactions between units within the same firm, whereas $95 \%$ of the cases subjected to market governance

${ }^{2}$ As a robustness test for our results, we conducted a hierarchical cluster analysis on the basis of the Ward method. This analysis, with minor exceptions, is consistent with the results of the latent class analysis in terms of the particular configurations of the governance mechanism characterizing the five clusters as well as the rank-ordering of the parameter values of the individual mechanisms across the clusters. 
occurred between independent partners. ${ }^{3}$ The general contractors we studied used hierarchical governance structures for instance for transactions concerning bulkhead construction in an underground car park, concrete and steel construction works for an office building, and the construction of concrete floors and ceilings in an airport building.

Configuration 3 displays the characteristics of a typical intermediate hybrid governance structure as identified by transaction cost economics (Makadok \& Coff, 2009; Williamson, 1991). With the exception of contractually agreed adaptation clauses, all dimensions of governance for this configuration lie in-between those for market and hierarchy. Examples of intermediate hybrid governance structures in our sample include transactions concerning the concrete works on a canal, steel construction work in a grocery storage building, and tunnel driving for a light rail system.

Interestingly, we find two further combinations of governance mechanisms that clearly deviate from market, hierarchical, and intermediate hybrid governance structures: Configuration 2 (for reasons explained below we label it the 'safeguarded management' governance structure) and configuration 4 (which we label 'selective risk management' governance structure) ${ }^{4}$. These two hybrids display the following distinctive features.

The safeguarded management configuration shares some features with the ideal-type of market governance, namely fairly low levels of management decision-rights on the side of the buyer, high levels of contractual guarantees and low adaptation measures. The distinctive features of the safeguarded management governance structure in which it clearly differs from ideal-typical

\footnotetext{
${ }^{3}$ The 5\% within-firm cases of market governance likely refer to buyer-supplier relations among profit centers within the same corporation. As Walker and Poppo (1991) have shown, the mean values of profit centers and outside suppliers in core transaction cost variables do not differ significantly.

4 These notions are our own and not used in the industry, as is generally the case for theoretical concepts. As far as we can tell, no alliance manager, for instance, would say s/he set up an intermediate hybrid. However, project managers recognized the three hybrid governance structures as distinct and could readily identify them.
} 
market governance are an input-oriented pricing scheme, e.g. pay for work efforts and/or costplus reimbursements for materials, coupled with more intense administrative controls and control decision-rights in the hands of the buyer. Since in all cases the transacting parties belong to different independent firms, safeguarded management is basically a particular kind of market relation between independent contractors, yet different from a classic intermediate hybrid. Our data show that safeguarded management typically governs transactions concerning the trades in a construction project, such as construction installation (e.g. heating, air conditioning, and utilities), plastering, roofing, painting, carpentry, and metal work. Examples from our sample include plaster work on a residential building, pipe collar lining in a car factory, and roofing for a medical centre.

The governance structure we labelled selective risk management is an extreme case in all dimensions of governance. As in ideal-typical market governance, price incentives are intense because suppliers are remunerated on the basis of performance outcomes. The buyer moreover has very low decision-rights and exercises very few administrative controls. However, the governance structure of selective risk management differs from the ideal-typical market in two main respects. First, despite high price incentives and lacking decision-rights and controls, the buyer hardly utilizes contractual guarantees as a safeguard. Second, instead the contract comprises extensive adaptation clauses so that the transaction can be easily adapted in case of change of circumstances; in addition, the buyer retains high levels of residuals rights of control for cases of unforeseen change and ensuing adaptation requirements. This configuration thus stands out for the way in which it handles ex-post adaptation of the transaction to changing circumstances. It is characterized by two ways of managing the risks of the exchanges involved: (1) comparatively extensive ex ante specification of potential contingencies and their consequences; (2) in cases of unexpected disturbances ex post, adaptation of the transaction by means of comparatively exten- 
sive residual decision-rights. Architectural, design, engineering, or planning services are the typical activities in the construction industry that according to our study are governed by selective risk management. Specific examples in our sample include the planning of building technology installations for an employment centre, construction planning management for a commercial building, and the calculation of statics for a potato storage building.

\section{Which Factors Help to Explain the Choice of Hybrid Governance Structures?}

Table 4 below shows the results of a univariate analysis of variance and Scheffé tests that indicate the significance of differences among cluster means of the five types of governance structures we found for the explanatory factors suggested in the theory section above. Results indicate that the core transaction cost theory variables specific investments and uncertainty explain variance across the five governance structures we found, but so do explanatory variables inspired by the embeddedness perspective we invoked, namely task complexity, past collaboration, trust, and industry norms. Transaction volume and duration, however, do not discriminate across the governance structures. In the following, we discuss how these results may help us better to understand hybrid governance structures.

Insert Table 4 about here

Intermediate hybrid. Recall that as its name suggests, this type of hybrid governance structure occupies an intermediate position between market and hierarchical governance structures in all dimensions of governance. In line with transaction cost theory's predictions, it also inhabits this intermediate position with regard to the theory's core explanatory variables. Results of the latent class analysis presented in Table 3 above indicate that asset specificity increases from market governance, through intermediate hybrid governance structures, and reaches its highest value for 
the hierarchical governance structure. With regard to uncertainty, the same pattern emerges, again confirming transaction cost theory predictions. With regard to the other potential explanatory variables too, bar one, this type of hybrid consistently lies in between the extremes of market and hierarchical governance. A low level of trust in the supplier represents the sole exception to this intermediary position. The Scheffé tests reveal, however, that none of the tested explanatory variables significantly discriminates statistically between intermediary hybrids and market or hierarchical governance.

In order further to explore how the proposed contingencies jointly affect the choice between intermediate hybrid and market governance, we conducted a multinomial regression analysis (see Table 5).

Insert Table 5 about here

Results reveal that the odds of intermediate hybrids being chosen over market governance increase when asset specificity is higher and transaction volumes are larger than for ideal-typical market governance. Larger specific investments and transaction volumes entail increased risk of transaction hazards. Intermediate hybrids mitigate these risks by realizing comparatively higher levels of contractual safeguards, administrative controls, and adaptability than in ideal-typical market relations. Our findings regarding the influence of asset specificity and transaction volume on the choice of intermediate hybrids over market governance are thus fully consistent with received transaction cost reasoning (Rindfleisch et al., 2010).

We further find that more frequent past collaboration also increases the odds of choosing an intermediate hybrid governance structure over market governance, while it decreases the odds in relation to hierarchical governance. With regard to this explanatory variable too, intermediate hybrids thus seem to occupy a middle ground between market and hierarchy. Substantively, our 
findings indicate that repeated collaboration is associated with increased odds for realizing more extensive and intense types of governance. This finding, however, is somewhat in disagreement with an explanation forwarded in the embeddedness literature that focuses on how past collaboration breeds familiarity and trust, leading to less need for formal monitoring and safeguards (Parkhe, 1993) as well as less extensive formal adaptation, administrative control, and conflict resolution mechanisms (Reuer \& Ariño, 2007). It is, however, consistent with an alternative explanation that has been offered in the literature. In their study of IT services contracts, Argyres et al. (2007) found that repeated exchanges between two firms lead to greater effort at contingency planning in subsequent contracts. Mayer and Argyres (2004) explain similar case study findings as the result of processes in which the transaction partners over time gain experience at working together, including learning how to contract with each other. Rather than triggering the development of relational attributes that serve as substitutes for formal governance, as suggested by embeddedness arguments, past collaboration in this view allows for more refined and comprehensive contracting as transaction partners over time learn how to better govern their transactions. An additional explanation might be that repeated collaboration fuels more extensive types of interaction, asking for more intense monitoring.

In sum, our results suggest that intermediate hybrids are chosen over market governance when transaction hazards associated with greater transaction volumes and specific investments are larger than under ideal-typical market governance conditions (yet not as large as to require hierarchical integration) and when the transaction partners have repeatedly interacted in the past. These findings suggest the economizing logic of transaction cost theory suffices to explain the choice of intermediate hybrids, yet can be complemented with a contractual learning logic. 
Safeguarded management. Recall that safeguarded management shares many characteristics of typical market governance, yet foregoes strong price incentives and instead relies on extensive contractual guarantees. We find that safeguarded management displays the lowest levels of uncertainty and task complexity among all five governance structures, significantly lower than for both market and hierarchical governance structures. Safeguarded management further occupies an extreme position with regard to two of the three embeddedness variables, as it is chosen when a buyer has little past experience with a supplier and invests little trust. Finally, safeguarded management is the governance structure of choice when asset specificity is low and transactions are subject to comparatively intense industry norms. The results of the Scheffé tests reveal that two conditions in particular influence the choice between safeguarded management and market governance: significantly greater prevalence of industry norms and lower task complexity.

From a theoretical point of view, what might then be the inner logic of the safeguarded management governance structure? While a form of market-like governance between independent contractors, safeguarded management relies on payment for work efforts and/or cost-plus reimbursements for materials rather than on output-based remuneration. Safeguarded management then seems to compensate the less intense price incentives for suppliers that are associated with input-oriented pricing by means of higher levels of buyer control. Input-oriented pricing scheme creates the risk of shirking (Eisenhardt, 1989). However, due to the particular configuration of the safeguarded management governance structure, shirking may be less of a problem for three reasons. First, the complementary governance mechanisms of control decision-rights and administrative controls mechanisms limit the opportunity for shirking by institutionalizing formal behavioural control (Dekker, 2004; Hennart, 1993; Mayer \& Salomon, 2006). Second, these control mechanisms can be effective, because safeguarded management is utilized under conditions of very low levels of uncertainty and task complexity, which makes behaviour and outcomes more 
predictable and control thus feasible (Mayer \& Nickerson, 2005; Ouchi, 1979). Third, by providing accepted blueprints, standards and rules for behaviour industry norms enhance the predictability of supplier behaviour and outcomes and thus motivate the use of input-oriented control mechanisms. Furthermore, the perceived legitimacy of industry norms through regulative, normative, and cultural cognitive mechanisms that advance compliance (Scott, 2001) will reduce the risk of opportunistic behaviour. Industry norms lower monitoring and enforcement costs, as they provide widely accepted performance standards and blueprints for verifying performance. Moreover, they provide a low-cost substitute for formal administrative controls and safeguards, as reputation effects and the possibility of social sanctioning discourage transacting parties from opportunistic behaviour (Chiles \& McMackin, 1996; Hill, 1990).

Aside from the risk of shirking, limited past collaboration and low trust may provide further reasons for institutionalizing comparatively more control in safeguarded management than in ideal-typical market governance structures. If a buyer has little or no experience with a supplier and therefore, or for other reasons, does not invest much trust in the supplier, the buyer will enhance controls in order to safeguard her interests (Dekker \& Van den Abbeele, 2010; Klein Woolthuis et al., 2005). Under the noted conditions, safeguarded management is practiced almost as frequently in our sample as ideal-typical market governance and, moreover, is perceived to be equally satisfactory.

The empirical findings of the multinomial regression analysis reported in Table 5 lend support to the theoretical reasoning regarding the inner logic of safeguarded management outlined above. All other things equal, we find that safeguarded management is chosen over market governance when asset specificity is larger than in typical market governance so that more extensive safeguards are required. Complementing standard transaction cost reasoning, we also find 
that safeguarded management is more likely to be triggered under conditions of low task complexity and when strong industry norms undergird the exchange.

In sum, these findings suggest that safeguarded management is chosen over ideal-typical market governance, first, because input-oriented control of supplier exchange behaviour is the comparatively more efficient form of contracting under conditions of lower levels of task complexity and strong industry norms, as both factors reduce contracting and monitoring costs (Eisenhardt, 1988; Hennart, 1993). Second, safeguarded management is chosen over ideal-typical market governance also because lower task complexity and more extensive industry norms enhance task programmability and outcome measurability and thus the buyer's ability effectively and efficiently to control the supplier's transaction behaviour (Eisenhardt, 1985) and to adapt it by means of exercising rights of decision control.

Selective risk management. Recall that both selective risk management and typical market governance rely on strong price incentives and grant considerable decision-rights to the supplier; yet selective risk management differs from typical market governance by instituting low levels of contractual guarantees and administrative controls as well as sizeable residual decision-rights and extensive contractual adaptation clauses. According to our results (see Table 4), selective risk management is characterized by conditions of low asset specificity, low task complexity and the highest levels of trust and industry norms of all found governance structures. As the ANOVA shows, this latter condition is the only one, however, discriminating the choice of selective risk management from market governance that is statistically significant.

What might be the theoretical logic of selective risk management? First, it seems that compared to ideal-typical market governance, the presence of trust and embeddedness in industry norms allow the transacting parties to economize on the monitoring and enforcement costs asso- 
ciated with formal safeguards provided by contractual guarantees and administrative controls. The presence of industry norms further reduces monitoring and enforcement costs, as normative pressure from industry peers and the threat of social sanctioning reduce opportunistic behaviour (Uzzi, 1996). Trust can substitute for more formal and more costly forms of control, such as contractual guarantees and administrative controls (Gulati \& Nickerson, 2008). Ryu, Min and Zushi (2008) demonstrate that a supplier's trustworthy behaviour is associated with lower degrees of buyer control over the key decisions of the supplier. In the context of the construction industry, Ngowi (2007) presents evidence that partner trustworthiness reduces the need for contractual safeguarding clauses. In their study in the Hong Kong construction industry, Lui and Ngo (2005) moreover find that trust enhances supplier acquiescence, i.e. suppliers are more inclined to follow the requests and actions of the buyer even at the expense of their own short-term interests. As a consequence, there is less need for formal controls. The particularities of the governance structure of selective risk management thus match a pattern where embeddedness substitutes for more formal forms of control.

Second, compared to ideal-typical market governance, selective risk management seems to substitute ex ante incentive contracting and on-going administrative control by ex post contingency contracting and residual decision-rights. The low levels of contractual guarantees and administrative controls indicate that it is difficult for the exchange partners to define tight ex ante contracts and to assess performance on an on-going basis. While we have no direct empirical evidence for these conditions, such difficulties could arise due to the ambiguity or tacitness of the contracted tasks, e.g. knowledge-intensive tasks (Simonin, 1999), or due to on-going adaptation needs that for example arise from the dependence of task specification and fulfilment on specific results of other tasks that are only completed sometime into the project. As a remedy for these ex ante task specification difficulties, the parties instead formulate extensive contractual adaptation 
clauses by which they seek to anticipate possible future contingencies and their implications for the terms of contract. Since even these contingent contracts may be incomplete (Hart \& Moore, 1999), the parties moreover agree on substantial residual decision-rights for the principal who can thus intervene and decide in cases not covered by the contract. In sum, when ex ante specifications of contract and performance cannot be effective, and ideal-typical market governance thus is problematic, the partners resort to selective risk management, as this governance structure entails governance mechanisms that provide extensive ex post adaptations of the terms of contract.

Such ex post adaption mechanisms, however, bear uncertainty and risks for the parties, as it is difficult for them to determine ex ante what exactly they will have to provide and what they will receive in return. The parties will be more inclined to accept these risks, however, if they have reason to be less concerned about possible opportunistic behaviour of the exchange partner. When parties to an exchange trust one another and can count on behavioural norms of appropriate behaviour established in the industry, opportunistic behaviour is less likely (Nooteboom et al., 1997; Uzzi, 1996). We therefore suggest that these conditions are conducive to favouring ex post specifications of tasks as realized in selective risk management over ex ante specification as realized in ideal-typical market governance.

Results of the logistic regression analysis (see Table 5) indicate that the main transaction cost theoretical variables do not contribute to the explanation of when selective risk management is preferred over ideal-typical market governance. Rather, embeddedness in industry norms is the only of the studied contingencies that helps to explain the choice of selective risk management over ideal-typical market governance. This finding is consistent with the argument we offered above concerning the inner logic of selective risk management.

In sum, results suggest that the governance structure of selective risk management is chosen when more intense industry norms allow the parties to economize on contractual guarantees and 
administrative controls, thus economizing on contracting, monitoring and conflict resolution costs that would arise in ideal-typical market governance. Moreover, these conditions reduce the perceived risk of opportunistic behaviour so that the parties are more inclined to accept ex post specifications of tasks by means of contractual adaptation clauses and residual decision-rights.

Together, the empirical results for the three hybrid governance structures indicate that the core explanatory concept of transaction cost economics—asset specificity—contributes to explaining the choice of the safeguarded management and intermediate hybrids over ideal-typical market governance. According to our findings, asset specificity however plays no role in accounting for the choice of selective risk management. Moreover, our results also show that explanatory concepts emphasized by other theoretical perspectives, notably task complexity, past collaboration and industry norms, in different combinations also significantly contribute to better understanding when each of the three hybrids we identified is chosen over market governance. As we outlined in the theory section and discussed in the context of the empirical results of this study, these added notions are largely compatible with transaction cost reasoning. We thus conclude that it might be fruitful to incorporate these concepts when seeking to arrive at an extended explanation of the variety of hybrid governance structures.

The question remains, however, how we can account for the choice among the three types of hybrids we identified. Since the basic theoretical arguments for explaining the differential choices would be along the same lines as those offered for the comparisons of the hybrids with market governance, we however keep this discussion brief. The multinomial regression reported in Table 6 provides pertinent results.

Insert Table 6 about here 
Findings show that safeguarded management is more likely to be chosen over selective risk management under conditions of lower trust and lower uncertainty. The added safeguards and administrative controls provided by safeguarded management can be interpreted as a response to reduced trust (Klein Woolthuis et al., 2005), while lower uncertainty is conducive to the effectiveness and efficiency of these governance mechanisms (Ouchi, 1979). Results further indicate that the intermediate hybrid governance structure is more likely to be chosen over selective risk management under conditions of greater transaction volumes, lower trust, and lower prevalence of industry norms. Again, the comparatively more extensive decision and control rights as well as administrative controls provided by intermediate hybrids can account for this finding, as greater transaction volumes, lower trust, and lower prevalence of industry norms increase potential transaction hazards. Finally, results indicate that intermediate hybrids prevail over safeguarded management under conditions of greater transaction volumes and more frequent past collaboration of the transacting parties. The greater decision needs and risks associated with larger transaction volumes can better be met by the comparatively greater decision-rights provided by intermediate hybrids, while the learning triggered by more frequent past collaboration (Mayer \& Argyres, 2004) is reflected in the comparatively greater extensiveness of contractual adaptation clauses and administrative controls of intermediate hybrids. All these findings are consistent with our earlier theorizing.

\section{CONCLUSION}

The present study set out to enhance our understanding of the nature and explanation of different forms of hybrid governance structures (Ménard, 1996) that constitute the 'swollen middle' between market and hierarchy (Hennart, 1993). In contrast to earlier studies that focus on individual types of hybrid governance structures, the present research covers the whole range of governance 
structures in a given industry in order systematically to classify, compare and seek to explain the various forms of governance structures along the same dimensions of governance.

The present paper makes two main contributions to the literature on hybrid governance structures. Using data from the German construction industry, we find that the transacting parties utilize three distinct types of hybrid governance structures beyond market and hierarchy for governing their transactions: intermediate hybrids, as described by standard transaction cost theory, and two hybrid governance structures that deviate from intermediate hybrids in important respects: safeguarded management and selective risk management. This study provides novel insights into the characteristics of these two new types of hybrid governance structures. While one should interpret case frequency in classes only with great caution, the fact that more than half of the cases we studied realize governance structures that constitute hybrid governance arrangements lends further support to Hennart's (1993) assertion that most transaction are governed by a mix of market and hierarchical governance mechanisms, rather than by pure market or hierarchical governance.

Second, as its main theoretical contribution, this study offers an empirically and large Nbased typology of hybrid governance structures that complements earlier theorizing. Specifically, we argue theoretically and demonstrate empirically how the complexity of transactions and their embeddedness in on-going exchange relations and industry norms affect the comparative costs of governance and can thus contribute to explaining the variety of governance structures beyond market and hierarchy. Rather than taking the social and institutional environment in which parties transact as given, as is common in transaction cost studies, our results suggest that also acknowledging the embeddedness of transactions can contribute to our understanding of when particular hybrid governance structures will be chosen. As we have spelled out in the theory section, such extension is broadly consistent with transaction cost theory. 
Our findings have a number of implications for research on hybrid governance structures. First, our results demonstrate the fruitfulness of a configurational approach that is open to recognizing combinations of governance mechanisms that deviate from established archetypes. Second, our theoretical arguments outline, and empirical findings then underscore, the fruitfulness and indeed necessity of complementing standard transaction cost economics reasoning with embeddedness arguments when seeking to explain the variety of hybrid governance structures. Third, our theoretical arguments and empirical findings alert researchers to the important role that institutional theory and contexts can play for explaining hybrid governance structures and thus to the possibility that different configurations of governance mechanisms may arise in different institutional contexts. It thus seems worthwhile if future research would also be concerned with analysing the institutional context in which different governance structures emerge.

We do not claim, however, that task complexity, relational and institutional embeddedness provide the only possible explanations for the new hybrid governance structures we identify. Additional contingencies that have been proposed in the literature might equally play a role (see e.g. Makadok \& Coff, 2009; Ménard, 2004). The present study, however, did not contain the data necessary for testing other possible influence factors so that such enquiries have to be left for future research. Future research could for instance explore the impact of other dimensions of embeddedness on governance choice. Positional (position of firms within an overall industry structure) and structural embeddedness (the configuration of the network in which the exchange partners are embedded) could be two potentially fruitful candidates because they bring informational and monitoring advantages lowering transaction costs (Polidoro et al., 2011).

As a further fruitful avenue for future research, scholars might focus on the dynamics of governance. Depending on initial conditions, one might assume that the use of different governance structures is a function of time. Argyres and Mayer (2007) argue that firms over time learn 
how much and what kinds of detail to include in a contract. The developing contract design capabilities thus influence the evolution of governance choices. This might be especially true for longlasting and complex transactions. Case studies point in this direction (Kalnins \& Mayer, 2004; Zheng, Roehrich \& Lewis, 2008), but more large scale evidence is clearly desirable.

We acknowledge a number of limitations of our study that suggest further possibly fruitful avenues for future research. As our findings are based on a survey that intended to capture the variety of governance structures applied in a given industry using a uniform, theoretically-based conceptualization of governance, we do not have the data to analyse in greater detail the inner workings of the found governance structures. Case studies of the new hybrid governance structures we identified could complement our findings by analysing the exact interplay of the constituent governance mechanisms and further scrutinize the theoretical rationale we offered. Obviously, we need more empirical studies in other settings to determine whether the new hybrid governance structures we found bear significance beyond our particular sample and setting. The construction industry is a project-based industry (Gann \& Salter, 2000). One could therefore question to what extent our findings are influenced by the particularities of project-based industries, such as the unique and discontinuous nature of project-based work (Söderlund, 2000; Sydow, Lindkvist \& DeFillippi, 2004). While our single-industry study does not allow us to examine this question empirically, we believe for two main reasons that the industry setting does not systematically distort our findings. First, the level of analysis of the present study is the individual transaction between a buyer and a supplier, not the project. These transactions can be one-off or continuing across a number of successive projects, as any buyer-supplier relation in permanent firms. Since we measure the extent to which parties collaborated in the past, we control for the possible effects of temporary relations. Second, earlier research has shown that the core notions of the theories we invoke also hold within the context of the construction industry (see Kadefors, 2005; 
Lui \& Ngo, 2005; Ngowi, 2007; Winch, 1989). Especially when acknowledging, as we do, the potential influence of the embeddedness of transactions, a further concern might be that other types of hybrid governance structures will prevail in other industries to the extent that these industries differ in their members' social relations and institutions. Should other forms of hybrids indeed exist in other industries, this would lend further credence to our proposal to study varying combinations of governance mechanisms rather than fixed generic archetypes. Nevertheless, the construction industry seems particularly suited for examining a variety of governance structures, not least because in this comparatively conservative but highly competitive industry it seems rather unlikely that exotic, inefficient governance structures will prevail in any large number. While our setting is the German construction industry and we cannot make claims for other geographic settings, the products produced in this industry, the basic trades in construction, the set-up of construction projects, the roles of general contractors and their suppliers as well as the challenges they face in their interactions seem largely similar across countries (Costantino \& Pietroforte, 2002; Tuuli, Rowlinson \& Tas Yong, 2010; White \& Lui, 2005). We therefore do not believe that our setting and sample give rise to a unique, unparalleled picture of governance structures in the construction industry and their antecedents. While the present research underscores that different types of hybrid governance structures are both commonly used in the construction industry and perceived as satisfactory, future research should complement our perceptual measure of performance with objective measures in order to assess the comparative efficiency of different governance structures. Although it has been shown that relying on the buyer's view produces reliable data on characteristics of buyer-supplier relations (Heide \& John, 1990), future research could also extend our approach by including the views of both parties to a transaction. Finally, given the limitations of cross-sectional studies, we cannot rule out that the new hybrids we detected over time will be substituted by more effective and efficient forms. While we regard this as un- 
likely given the conservative stance and long experience with different forms of governance structures in the construction industry and the large number of cases of hybrids we found, future research could examine the fate of hybrid governance structures over time. Despite the noted limitations, we hope that the present study provides some inspiration for further probing the variety of governance structures and their explanation. 
Table 1: Ideal-typical characteristics of governance structures

\begin{tabular}{|c|c|c|c|}
\hline \multirow{2}{*}{$\begin{array}{l}\text { Governance } \\
\text { dimensions }\end{array}$} & \multicolumn{3}{|c|}{ Governance structure } \\
\hline & Market & Intermediate hybrid & Hierarchy \\
\hline $\begin{array}{l}\text { Ownership auton- } \\
\text { omy }\end{array}$ & $\begin{array}{l}\text { Parties have full ownership } \\
\text { over their respective re- } \\
\text { sources }\end{array}$ & $\begin{array}{l}\text { Shared ownership of re- } \\
\text { sources or joint decision- } \\
\text { making over resources }\end{array}$ & $\begin{array}{l}\text { Buyer has right to deploy } \\
\text { supplier's resources by fiat }\end{array}$ \\
\hline Incentive intensity & $\begin{array}{l}\text { Output pricing } \\
\text { Intense contractual guaran- } \\
\text { tees }\end{array}$ & $\begin{array}{l}\text { Output or input pricing of } \\
\text { medium incentive intensity } \\
\text { Medium intensity of con- } \\
\text { tractual guarantees }\end{array}$ & $\begin{array}{l}\text { Input pricing } \\
\text { No or few contractual guar- } \\
\text { antees }\end{array}$ \\
\hline $\begin{array}{l}\text { Administrative } \\
\text { controls }\end{array}$ & $\begin{array}{l}\text { No or few administrative } \\
\text { controls }\end{array}$ & $\begin{array}{l}\text { Medium intensity of admin- } \\
\text { istrative controls }\end{array}$ & $\begin{array}{l}\text { Intense administrative con- } \\
\text { trols }\end{array}$ \\
\hline Adaptation & $\begin{array}{l}\text { Parties autonomously adapt } \\
\text { to changing conditions }\end{array}$ & $\begin{array}{l}\text { Medium autonomy of } \\
\text { transacting parties in adapt- } \\
\text { ing to changing conditions }\end{array}$ & $\begin{array}{l}\text { Honouring the contract, the } \\
\text { buyer holds the right to } \\
\text { adapt the transaction to } \\
\text { unanticipated changes }\end{array}$ \\
\hline
\end{tabular}


Table 2: Descriptive statistics of and correlations between variables used in the analyses

\begin{tabular}{|c|c|c|c|c|c|c|c|c|c|c|c|c|c|c|c|c|c|c|}
\hline & Mean & $\begin{array}{l}\text { Std. } \\
\text { Dev. }\end{array}$ & 2 & 3 & 4 & 5 & 6 & 7 & 8 & 9 & 10 & 11 & 12 & 13 & 14 & 15 & 16 & 17 \\
\hline 1. Specific investments & 3.0 & 1.2 & $.258 \dagger$ & $.322 \dagger$ & $.201 \dagger$ & .012 & $.384 \dagger$ & -.089 & $-.161 \dagger$ & $.170 \dagger$ & $.131 *$ & $.151 *$ & $-.240 \dagger$ & .098 & $.113^{*}$ & $.115^{*}$ & -.066 & $.300 \dagger$ \\
\hline 2. Uncertainty & 2.6 & 0.8 & 1 & $.399 \dagger$ & $.152 \dagger$ & .091 & .037 & $-.239 \dagger$ & -.010 & .001 & -.060 & $.142 *$ & $-.184 \dagger$ & .030 & .079 & $.174 *$ & -.104 & $.228 \dagger$ \\
\hline $\begin{array}{l}\text { 3. Management deci- } \\
\text { sion-rights on busi- } \\
\text { ness policy }\end{array}$ & 2.1 & 1.5 & & 1 & $.468 \dagger$ & $.146 \dagger$ & $.439 \dagger$ & $-.513 \dagger$ & $-.183 \dagger$ & $.175 \dagger$ & .071 & $-.127 *$ & $-.254 \dagger$ & $.227 \dagger$ & $.430 \dagger$ & $.184 *$ & -.057 & $.828 \dagger$ \\
\hline $\begin{array}{l}\text { 4. Control decision- } \\
\text { rights on resource } \\
\text { allocation }\end{array}$ & 2.8 & 1.0 & & & 1 & $.342 \dagger$ & $.395 \dagger$ & $-.304 \dagger$ & $-.287 \dagger$ & $.141^{*}$ & -0.88 & -.106 & -.079 & .105 & $.212 \dagger$ & $-.141^{*}$ & -0.10 & $.339 \dagger$ \\
\hline $\begin{array}{l}\text { 5. Residual decision- } \\
\text { rights with regard to } \\
\text { adaptation }\end{array}$ & 3.6 & 0.8 & & & & 1 & .080 & $-.183 \dagger$ & -.024 & -.029 & -.084 & -.093 & -.067 & $.129 *$ & .090 & .027 & .045 & $.149 \dagger$ \\
\hline $\begin{array}{l}\text { 6. Administrative con- } \\
\text { trols }\end{array}$ & 2.5 & 0.8 & & & & & 1 & .015 & $-.229 \dagger$ & $.439 \dagger$ & $.135^{*}$ & .017 & $-.157 *$ & $.181 \dagger$ & $.147 *$ & -.109 & $-.266 \dagger$ & $.351 \dagger$ \\
\hline $\begin{array}{l}\text { 7. Contractual guaran- } \\
\text { tees }\end{array}$ & 4.0 & 1.2 & & & & & & 1 & .025 & $.274 \dagger$ & .034 & -.011 & $.146^{*}$ & -.077 & $-.309 \dagger$ & $-.157^{*}$ & $-.149^{*}$ & $-.545 \dagger$ \\
\hline 8. Output/input pricing & -0.1 & 0.3 & & & & & & & 1 & -.064 & -.047 & .075 & -.075 & -.065 & -.040 & .101 & $-.142 *$ & -.062 \\
\hline $\begin{array}{l}\text { 9. Contractual adapta- } \\
\text { tion clauses }\end{array}$ & 3.8 & 0.9 & & & & & & & & 1 & .033 & -.044 & $-.131 *$ & .112 & -.026 & -.070 & $-.239 \dagger$ & .054 \\
\hline $\begin{array}{l}\text { 10. Transaction volume } \\
\text { (in mio.) }\end{array}$ & 2.1 & 7.9 & & & & & & & & & 1 & $.414 \dagger$ & .029 & $-.149 *$ & .053 & .101 & .097 & $.117 *$ \\
\hline $\begin{array}{l}\text { 11. Project duration (in } \\
\text { months) }\end{array}$ & 8.0 & 8.6 & & & & & & & & & & 1 & -0.82 & $-.173 \dagger$ & -0.77 & .075 & -.083 & -.057 \\
\hline 12. Task complexity & 2.7 & 1.1 & & & & & & & & & & & 1 & -.150 & -.103 & $-.141 *$ & .083 & $-.288 \dagger$ \\
\hline $\begin{array}{l}\text { 13. Satisfaction with } \\
\text { governance of } \\
\text { transaction }\end{array}$ & 3.5 & 0.8 & & & & & & & & & & & & 1 & $.242 \dagger$ & .103 & -.026 & $.198 \dagger$ \\
\hline 14. Past collaboration & 4.0 & 1.9 & & & & & & & & & & & & & 1 & .089 & .034 & $.475 \dagger$ \\
\hline 15. Trust & 2.5 & 1.2 & & & & & & & & & & & & & & 1 & -.091 & $.194 \dagger$ \\
\hline 16. Industry norms & 3.2 & 1.5 & & & & & & & & & & & & & & & 1 & .017 \\
\hline 17. Parties in same firm & 1.3 & 0.5 & & & & & & & & & & & & & & & & 1 \\
\hline
\end{tabular}

$\dagger=\mathrm{p}<0.01 ; *=\mathrm{p}<0.05$ 
Table 3. Configurations of governance mechanisms: Cluster means of Latent Class analysis $(\mathbf{n}=\mathbf{2 2 3})$

\begin{tabular}{|c|c|c|c|c|c|}
\hline Latent classes & $\begin{array}{c}\text { Configuration } \\
1 \\
(\mathbf{n}=67,29.9 \%) \\
\text { Market } \\
\text { (M) }\end{array}$ & $\begin{array}{c}\text { Configuration } \\
\mathbf{2} \\
(\mathbf{n}=\mathbf{5 8}, \mathbf{2 6 . 1 \%}) \\
\text { Safeguarded } \\
\text { Management } \\
(\mathrm{SaM}) \\
\end{array}$ & $\begin{array}{c}\text { Configuration } \\
\mathbf{3} \\
(\mathbf{n}=\mathbf{3 2}, \mathbf{1 4 . 5 \%}) \\
\text { Intermediate Hybrid } \\
(\mathrm{HY})\end{array}$ & $\begin{array}{c}\text { Configuration } \\
\mathbf{4} \\
(\mathbf{n}=\mathbf{4 0}, \mathbf{1 7 , 7 \%}) \\
\text { Selective risk manage- } \\
\text { ment } \\
(\text { SeRM }) \\
\end{array}$ & $\begin{array}{c}\text { Configuration } \\
5 \\
(\mathbf{n}=\mathbf{2 6}, \mathbf{1 1 . 7 \%}) \\
\text { Hierarchy } \\
\text { (H) }\end{array}$ \\
\hline \multicolumn{6}{|l|}{ Ownership Autonomy } \\
\hline $\begin{array}{l}\text { Management decision-rights on } \\
\text { general business policy issues }\end{array}$ & -0.62 & -0.59 & +0.95 & -0.61 & +1.86 \\
\hline $\begin{array}{l}\text { Control decision-rights on re- } \\
\text { source allocation }\end{array}$ & -0.37 & -0.03 & +0.39 & -0.42 & +0.93 \\
\hline \multicolumn{6}{|l|}{ Incentive intensity } \\
\hline Contractual guarantees & +0.66 & +0.53 & -0.52 & -0.83 & -0.99 \\
\hline $\begin{array}{l}\text { Input- /output orientation of } \\
\text { pricing scheme }[>0 \text {, output- } \\
\text { oriented; }<0 \text { input-oriented] }\end{array}$ & +0.37 & -0.60 & -0.15 & +0.46 & -0.60 \\
\hline Administrative Controls & -0.15 & 0.00 & +0.27 & -0.70 & +1.03 \\
\hline${\text { Residual Decision-Rights }{ }^{1)}}$ & -0.25 & -0.18 & -0.03 & +0.62 & 0.01 \\
\hline Contractual Adaptation Clauses & -0.13 & -0.11 & +0.49 & +0.84 & -0.92 \\
\hline \multicolumn{6}{|l|}{ Passive covariates } \\
\hline $\begin{array}{l}\text { Percent cases where transacting } \\
\text { parties belong to same firm }\end{array}$ & $5 \%$ & $0 \%$ & $77 \%$ & $20 \%$ & $100 \%$ \\
\hline Specific investments & -0.18 & -0.11 & +0.38 & -0.09 & +0.74 \\
\hline Uncertainty & -0.02 & -0.21 & +0.24 & +0.02 & +0.62 \\
\hline $\begin{array}{l}\text { Satisfaction with governance of } \\
\text { transaction }\end{array}$ & 3.44 & 3.45 & 3.29 & 3.08 & 4.00 \\
\hline
\end{tabular}

Bold: high cluster center values; Italic: low cluster center values.

1) High values indicate greater autonomous decision-making rights concerning adaptations by the general contractor; low values indicate greater autonomous decision-making rights concerning adaptations by the supplier; medium values indicate coordinated adaptation (shared decision-making). 
Table 4: Univariate ANOVA of governance characteristics across clusters (cluster means averages; all variables centred, except transaction volume and duration).

\begin{tabular}{|c|c|c|c|c|c|c|c|}
\hline \multirow[t]{2}{*}{ Variables } & \multirow[b]{2}{*}{$\mathrm{F}$} & \multicolumn{5}{|c|}{ Governance structures } & \multirow{2}{*}{$\begin{array}{c}\text { Significant } \\
\text { pairwise } \\
\text { differences } \\
\text { in cluster } \\
\text { means } \\
\text { (Scheffé } \\
\text { test) }\end{array}$} \\
\hline & & $\begin{array}{l}\text { Market } \\
\text { (M) }\end{array}$ & $\begin{array}{c}\text { Safeguarded } \\
\text { Management } \\
\\
(\mathrm{SaM})\end{array}$ & $\begin{array}{c}\text { Intermediate } \\
\text { Hybrid } \\
\text { (IH) }\end{array}$ & $\begin{array}{c}\text { Selective } \\
\text { risk man- } \\
\text { agement } \\
(\mathrm{SeRM})\end{array}$ & $\begin{array}{c}\text { Hierarchy } \\
\text { (H) }\end{array}$ & \\
\hline $\begin{array}{l}\text { Specific } \\
\text { investments }\end{array}$ & $6.31 * * *$ & -.17 & -.12 & .38 & -.08 & .73 & $\begin{array}{l}\mathrm{H}>\mathrm{M}^{* *} \\
\mathrm{SaM}^{* *} \\
\mathrm{SeRM}^{* *}\end{array}$ \\
\hline Uncertainty & $3.61 * *$ & .01 & -.22 & .23 & .02 & .60 & $\mathrm{H}>\mathrm{SaM}^{* *}$ \\
\hline $\begin{array}{l}\text { Transaction } \\
\text { volume }\end{array}$ & 1.29 & 1.63 & 1.80 & 2.70 & 1.42 & 6.01 & \\
\hline $\begin{array}{l}\text { Transaction } \\
\text { duration }\end{array}$ & 1.34 & 9.83 & 7.38 & 8.95 & 7.53 & 5.55 & \\
\hline $\begin{array}{l}\text { Task com- } \\
\text { plexity }\end{array}$ & $5.48 * * *$ & .07 & -.42 & .13 & -.18 & .56 & $\begin{array}{l}\mathrm{H}>\mathrm{SaM}^{* *} \\
\mathrm{SeRM} * \\
\mathrm{M}>\mathrm{SaM}^{*}\end{array}$ \\
\hline $\begin{array}{l}\text { Past collab- } \\
\text { oration }\end{array}$ & $8.03^{* * *}$ & -.17 & -.30 & .34 & -.05 & .76 & $\begin{array}{l}\mathrm{H}>\mathrm{M}^{* *} \\
\mathrm{SaM}< \\
\mathrm{IH}^{* *}, \mathrm{H}^{* * *} \\
\mathrm{SeRM}< \\
\mathrm{H}^{* *}\end{array}$ \\
\hline Trust & $3.41 * *$ & .02 & -.39 & -.17 & .26 & .02 & $\begin{array}{l}\mathrm{SaM}< \\
\mathrm{SeRM}^{* *}\end{array}$ \\
\hline $\begin{array}{l}\text { Industry } \\
\text { norms }\end{array}$ & $3.66 * *$ & -.23 & .27 & -.12 & .42 & .08 & $\begin{array}{l}\mathrm{M}<\mathrm{SaM}^{*} \\
\mathrm{SeRM}^{* *}\end{array}$ \\
\hline
\end{tabular}

$* * *=\mathrm{p}<0.01 ; * *=\mathrm{p}<0.05 ; *=\mathrm{p}<0.10$ 
Table 5: Beta values of multinomial logistic regression on cluster membership for hybrid and hierarchical governance structures.

\begin{tabular}{|c|c|c|c|c|c|c|c|}
\hline \multirow{2}{*}{\begin{tabular}{l}
\multicolumn{1}{c}{ Cluster / } \\
Antecedents \\
$\begin{array}{l}\text { Reference } \\
\text { category }\end{array}$
\end{tabular}} & \multicolumn{2}{|c|}{$\begin{array}{l}\text { Safeguarded } \\
\text { Management }\end{array}$} & \multicolumn{2}{|c|}{$\begin{array}{l}\text { Selective Risk } \\
\text { Management }\end{array}$} & \multicolumn{2}{|c|}{$\begin{array}{c}\text { Intermediate } \\
\text { Hybrid }\end{array}$} & \multirow{2}{*}{$\begin{array}{c}\text { Hierarchy } \\
\text { Market }\end{array}$} \\
\hline & Market & Hierarchy & Market & Hierarchy & Market & Hierarchy & \\
\hline $\begin{array}{l}\text { Specific } \\
\text { investments }\end{array}$ & $.498 *$ & -.158 & .172 & -.484 & $.655^{* *}$ & .000 & $.655^{*}$ \\
\hline Uncertainty & -.139 & $-1.379 * * *$ & .378 & $-.862 * *$ & .228 & $-1.012 * *$ & $1.240 * * *$ \\
\hline $\begin{array}{l}\text { Transaction } \\
\text { volume }\end{array}$ & -.124 & -.249 & -.124 & -.250 & $.214^{*}$ & .088 & .125 \\
\hline $\begin{array}{l}\text { Transaction } \\
\text { duration }\end{array}$ & -.034 & $.159 *$ & -.020 & $.174 * *$ & -.042 & $.151 *$ & $-.193 *$ \\
\hline $\begin{array}{l}\text { Task } \\
\text { complexity }\end{array}$ & $-.603 * *$ & $-.898 * *$ & -.297 & -.592 & -.211 & -.506 & .295 \\
\hline $\begin{array}{l}\text { Past } \\
\text { collaboration }\end{array}$ & -.007 & $-2.464 * * *$ & .309 & $-2.148 * *$ & $.914 * *$ & $-1.542 * *$ & $2.456^{* * *}$ \\
\hline Trust & -.360 & -.051 & .277 & .586 & -.403 & -.094 & -.309 \\
\hline $\begin{array}{l}\text { Industry } \\
\text { norms }\end{array}$ & $.589 * * *$ & .391 & $1.069 * * *$ & $.872 * *$ & .327 & .129 & .198 \\
\hline $\mathrm{CD}(\mathrm{n})$ & n.s. & n.s. & n.s. & n.s. & n.s. & n.s. & n.s. \\
\hline \multicolumn{8}{|l|}{$\begin{array}{l}\text { Model fit } \\
\text { statistics }\end{array}$} \\
\hline Chi-square & \multicolumn{7}{|c|}{$202.535 * * *$} \\
\hline $\begin{array}{l}\text { Nagelkerke's } \\
\text { R square }\end{array}$ & \multicolumn{7}{|c|}{.658} \\
\hline $\mathrm{N}=$ & \multicolumn{7}{|c|}{205} \\
\hline
\end{tabular}


Table 6: Beta values of multinomial logistic regression on cluster membership for hybrid governance structures.

\begin{tabular}{|c|c|c|c|}
\hline $\begin{array}{c}\text { Cluster / } \\
\text { Antecedents }\end{array}$ & $\begin{array}{l}\text { Safeguarded } \\
\text { Management }\end{array}$ & $\begin{array}{c}\text { Intermediate } \\
\text { Hybrid }\end{array}$ & $\begin{array}{c}\text { Intermediate } \\
\text { Hybrid }\end{array}$ \\
\hline Reference category & $\begin{array}{l}\text { Selective Risk } \\
\text { Management }\end{array}$ & $\begin{array}{l}\text { Safeguarded } \\
\text { Management }\end{array}$ & $\begin{array}{l}\text { Selective Risk } \\
\text { Management }\end{array}$ \\
\hline $\begin{array}{l}\text { Specific } \\
\text { investments }\end{array}$ & .326 & .158 & .483 \\
\hline Uncertainty & $-.518 *$ & .367 & -.150 \\
\hline $\begin{array}{l}\text { Transaction vol- } \\
\text { ume }\end{array}$ & .001 & $.337 * *$ & $.338 * *$ \\
\hline $\begin{array}{l}\text { Transaction dura- } \\
\text { tion }\end{array}$ & -.014 & -.008 & -.022 \\
\hline $\begin{array}{l}\text { Task } \\
\text { complexity }\end{array}$ & -.306 & .392 & .086 \\
\hline $\begin{array}{l}\text { Past } \\
\text { collaboration }\end{array}$ & -.316 & $.922 * *$ & .606 \\
\hline Trust & $-.637 * *$ & -.043 & $-.680^{*}$ \\
\hline Industry norms & -.480 & -.262 & $-.743 * *$ \\
\hline $\mathrm{CD}(\mathrm{n})$ & n.s. & n.s. & n.s. \\
\hline \multicolumn{4}{|l|}{ Model fit statistics } \\
\hline Chi-square & \multicolumn{3}{|c|}{$202.535 * * *$} \\
\hline $\begin{array}{l}\text { Nagelkerke's R } \\
\text { square }\end{array}$ & \multicolumn{3}{|c|}{.658} \\
\hline $\mathrm{N}=$ & \multicolumn{3}{|c|}{205} \\
\hline
\end{tabular}


Appendix 1. Measurement of concepts

\begin{tabular}{|c|c|c|}
\hline $\begin{array}{l}\text { Variable } \\
\text { Cronbach's } \alpha \\
\text { and F-statistic }\end{array}$ & Items & Scale \\
\hline \multicolumn{3}{|c|}{ OWNERSHIP AUTONOMY } \\
\hline $\begin{array}{l}\text { Distribution of } \\
\text { management de- } \\
\text { cision-rights on } \\
\text { general business } \\
\text { policy issues in } \\
\text { the transaction } \\
\text { relationship } \\
\text { Cronbach's } \alpha 0.79 \\
\text { F }=20.469\end{array}$ & $\begin{array}{l}\text { Who had decision-making authority over the below decision issues within the focal } \\
\text { relationship: } \\
\text { (a) long-term and medium-term business policy of provider (e.g. investments); } \\
\text { (b) type and volume of financing of investments of provider; } \\
\text { (c) use of profit from activities; } \\
\text { (d) sale of factors of production for this activity }\end{array}$ & \multirow[t]{2}{*}{$\begin{array}{l}\text { 5-point Likert scale: } \\
\text { (1) producer decides alone; } \\
\text { (2) mainly producer decides; } \\
\text { (3) both decide; } \\
\text { (4) mainly our company decides; } \\
\text { (5) our company decides alone }\end{array}$} \\
\hline $\begin{array}{l}\text { Distribution of } \\
\text { control decision- } \\
\text { rights on resource } \\
\text { allocation in the } \\
\text { transaction rela- } \\
\text { tionship } \\
\text { Cronbach's } \alpha 0.74 \\
\mathrm{~F}=12.495\end{array}$ & $\begin{array}{l}\text { Who had decision-making authority over the below decision issues within the focal } \\
\text { relationship: } \\
\text { (e) selection of raw materials or suppliers; } \\
\text { (f) selection or usage of factors of production (e.g. type and number of machines to } \\
\text { be used); } \\
\text { (g) change of factors of production; } \\
\text { (h) selection and/or deployment of employees (e.g. concerning quantity, qualifica- } \\
\text { tion, location of employment); } \\
\text { (i) type and degree of quality control; }\end{array}$ & \\
\hline
\end{tabular}




\begin{tabular}{|c|c|c|}
\hline \multicolumn{3}{|c|}{$\begin{array}{l}\text { ADMINISTRATIVE CONTROLS } \\
\text { ADDITIVE INDEX OF CC1 - CC5: CRONBACH'S A 0.79; F = 148.114 }\end{array}$} \\
\hline $\begin{array}{l}\text { CC1: Ex-ante and } \\
\text { ex-post calcula- } \\
\text { tions } \\
\text { Cronbach's } \alpha 0.91 \\
\mathrm{~F}=14,546\end{array}$ & $\begin{array}{l}\text { For this activity, we thoroughly calculated in advance } \\
\text { (a) costs of human and material resources to be employed; } \\
\text { (b) costs that could arise due to production site risks, performance disturbances or } \\
\text { performance deficits. } \\
\text { For this activity, we thoroughly calculated ex post } \\
\text { (c) costs of human and material resources employed; } \\
\text { (d) costs due to production site risks, performance disturbances or performance } \\
\text { deficits. }\end{array}$ & \multirow{5}{*}{$\begin{array}{l}\text { 5-point Likert scale ranging from (1) } \\
\text { not at all - (5) to a large extent. } \\
\text { Respondents were asked to indicate } \\
\text { on a 5-point Likert scale for each of } \\
\text { the studied monitoring and control } \\
\text { instruments to what extent the infor- } \\
\text { mation generated by the respective } \\
\text { instrument would entail positive or } \\
\text { negative consequences for the provid- } \\
\text { er. For the final measure, the use of a } \\
\text { mechanism was then weighted by its } \\
\text { impact. } \\
\text { In order to simplify and condense the } \\
\text { presentation of our results, for the cor- } \\
\text { relation and latent class analyses we } \\
\text { substituted our measures of the five } \\
\text { individual coordination and control } \\
\text { mechanisms with but one measure for } \\
\text { formal coordination and control by } \\
\text { forming a standardized additive index } \\
\text { of the individual values. We regard } \\
\text { this simplification as feasible and } \\
\text { justified because the five individual } \\
\text { coordination and control mechanisms } \\
\text { in a factor analysis load on one factor, } \\
\text { and the scale of the additive index of } \\
\text { the coordination and control mecha- } \\
\text { nisms is highly reliable (Cronbach's } \alpha \\
=0,79 \text { ). }\end{array}$} \\
\hline $\begin{array}{l}\text { CC2: Index fi- } \\
\text { gures } \\
\text { Cronbach's } \alpha 0.96 \\
\mathrm{~F}=61.606\end{array}$ & $\begin{array}{l}\text { For this relationship, we produced a sizeable amount of index figures (e.g. with } \\
\text { regard to returns on investment, capacity utilization, or productivity), concerning } \\
\text { (e) the human and material resources employed; } \\
\text { (f) the quality and/or quantity of outputs produced; } \\
\text { (g) the meeting of deadlines. }\end{array}$ & \\
\hline $\begin{array}{l}\text { CC3: Reports } \\
\text { Cronbach's } \alpha 0.83 \\
\mathrm{~F}=109.131\end{array}$ & $\begin{array}{l}\text { Within this relationship, there existed explicit duties to file performance reports in } \\
\text { form of } \\
\text { (k) cost reports; } \\
\text { (l) construction site reports; } \\
\text { (m) reports concerning the meeting of schedules. }\end{array}$ & \\
\hline $\begin{array}{l}\text { CC4: Planning } \\
\text { Cronbach's } \alpha 0.83 \\
\mathrm{~F}=127.058\end{array}$ & $\begin{array}{l}\text { Within this relationship there existed ample plans concerning } \\
\text { (n) processes, materials and capacities; } \\
\text { (o) the quality and/or quantity of outputs produced; } \\
\text { (p) production schedules and deadlines. }\end{array}$ & \\
\hline $\begin{array}{l}\text { CC5: Test and } \\
\text { screening proce- } \\
\text { dures } \\
\text { Cronbach's } \alpha 0.75 \\
\mathrm{~F}=94.540\end{array}$ & $\begin{array}{l}\text { Within this relationship, we intensively employed material and technical tests and } \\
\text { testing methods concerning } \\
\text { (q) the human and material resources employed; } \\
\text { I the quality and/or quantity of output produced. }\end{array}$ & \\
\hline
\end{tabular}




\begin{tabular}{|c|c|c|}
\hline \multicolumn{2}{|c|}{ INCENTIVE INTENSITY } & \multirow[b]{2}{*}{$\begin{array}{l}\text { 5-point Likert scale ranging from } \\
\text { (1) fully disagree - (5) fully agree }\end{array}$} \\
\hline $\begin{array}{l}\text { Level of specifica- } \\
\text { tion of contractu- } \\
\text { al guarantees } \\
\text { Cronbach's } \alpha 0.86 \\
\mathrm{~F}=25.042\end{array}$ & $\begin{array}{l}\text { Please characterize the degree of detail of the contract. } \\
\text { (a) The contract governing this transaction attempts to regulate all aspects and con- } \\
\text { tingencies of the project as detailed as possible; } \\
\text { (b) The contract governing this transaction stipulates with great precision contrac- } \\
\text { tual guarantees and safeguards (e.g. penalties) concerning the timely completion of } \\
\text { the activity or product; } \\
\text { (c) The contract governing this transaction stipulates with great precision contrac- } \\
\text { tual guarantees and safeguards (e.g. penalties) concerning the quality of the activity } \\
\text { or product. }\end{array}$ & \\
\hline $\begin{array}{l}\text { Pricing scheme } \\
{[\text { O ] = output }} \\
\text { pricing } \\
\text { [I] = input pric- } \\
\text { ing } \\
\text { Cronbach's } \alpha 0.79 \\
\mathrm{~F}=105.937\end{array}$ & $\begin{array}{l}\text { Which of the following pricing schemes for the settlement/payment of outputs } \\
\text { were used within the relationship? } \\
\text { (a) lump-sum payment for specified output [O] } \\
\text { (b) fee according to market prices [O] } \\
\text { (c) incentive pricing (e.g. premium or fine for meeting of failing targets) [O] } \\
\text { (d) cost-based pricing on the basis of ex-ante specifications of inputs [I] } \\
\text { (e) cost-based pricing plus fixed/variable profit mark-up [I] } \\
\text { (f) cost-based pricing for man-hrs [I]. }\end{array}$ & $\begin{array}{l}\text { Dummy (0) not used, } \\
\text { (1) used. } \\
\text { Since some of the pricing schemes } \\
\text { can be, and are, combined in practice, } \\
\text { it was feasible to construct an index } \\
\text { reflecting the degree of the output- } \\
\text { versus input-orientation of the pricing } \\
\text { scheme by adding the dummies for } \\
\text { the three output-oriented forms of } \\
\text { pricing and then subtracting the three } \\
\text { summed input-oriented pricing dum- } \\
\text { mies. Thus, the more positive the } \\
\text { value of the resulting index, the great- } \\
\text { er the output-orientation of the pricing } \\
\text { scheme; the more negative the value } \\
\text { of the index, the more input-oriented } \\
\text { is the pricing scheme. }\end{array}$ \\
\hline
\end{tabular}




\begin{tabular}{|c|c|c|}
\hline \multicolumn{2}{|c|}{ ADAPTATION RIGHTS } & \multirow{2}{*}{$\begin{array}{l}\text { Interviews with industry experts } \\
\text { 5-point Likert scale ranging from (1) } \\
\text { the supplier decides alone - (5) the } \\
\text { general contractor decides alone }\end{array}$} \\
\hline $\begin{array}{l}\text { Distribution of } \\
\text { residual decision- } \\
\text { rights with regard } \\
\text { to adaptations in } \\
\text { the transaction } \\
\text { relationship due } \\
\text { to unexpected } \\
\text { changes } \\
\text { Cronbach's } \alpha 0.78 \\
\mathrm{~F}=18.2\end{array}$ & $\begin{array}{l}\text { Who had decision-making authority over the below decision issues within the focal } \\
\text { relationship: } \\
\text { (j) adjustments of prices if unexpected changes should occur; } \\
\text { (k) adjustments of quantities if unexpected changes should occur; } \\
\text { (l) adjustments of performance specifications if unexpected changes should occur; } \\
\text { (m) production planning of provider (e.g. schedules) }\end{array}$ & \\
\hline \multicolumn{3}{|c|}{ CONTRACTUAL ADAPTATION MECHANISMS } \\
\hline $\begin{array}{l}\text { Contractual ad- } \\
\text { aptation } \\
\text { Cronbach's } \alpha 0.74 \\
\mathrm{~F}=11.80\end{array}$ & $\begin{array}{l}\text { Please characterize the extent to which the contract comprised regulations support- } \\
\text { ing adaptation of the transaction to changed circumstances. } \\
\text { With regard to adaptation, there were specific clauses concerning... } \\
\text { (a) mechanisms or procedures for price and/or quantity adjustments; } \\
\text { (b) mechanisms or procedures for the adjustment of performance specifications; } \\
\text { (c) procedures for the extensive exchange of information and/or documents in the } \\
\text { course of the exchange; } \\
\text { (d) regular work meetings and/or project consultations in the course of the ex- } \\
\text { change. }\end{array}$ & $\begin{array}{l}\text { 6-point Likert scale ranging from (1) } \\
\text { fully disagree - (6) fully agree }\end{array}$ \\
\hline \multicolumn{3}{|c|}{ TRANSACTION ATTRIBUTES } \\
\hline \multicolumn{3}{|c|}{\begin{tabular}{l|l} 
Uncertainty & \\
\end{tabular}} \\
\hline $\begin{array}{l}\text { Cronbach's } \alpha 0.70 \\
F=79.859\end{array}$ & $\begin{array}{l}\text { (a) We can assess the quality of the product or service provided on the basis of a } \\
\text { few criteria; } \\
\text { (b) It would be easy for the provider of this activity to conceal the quality of the } \\
\text { completed product or service (reverse coded); } \\
\text { (c) In case of qualitative and/or quantative failures, it is difficult to establish re- } \\
\text { sponsibilities (reverse coded); } \\
\text { (d) It is easy for us quickly to assess the quality of the completed product or ser- } \\
\text { vice; }\end{array}$ & $\begin{array}{l}\text { 6-point Likert scale ranging from (1) } \\
\text { fully disagree - (6) fully agree }\end{array}$ \\
\hline
\end{tabular}




\begin{tabular}{|c|c|c|}
\hline & $\begin{array}{l}\text { (e) It is easy to describe and structure the production process in advance; } \\
\text { (f) It is difficult to estimate in advance the quality and/or quantity of resources } \\
\text { needed for conducting this activity (reverse coded); } \\
\text { (g) During the activity, immediate changes in the way of conducting the activity } \\
\text { can become necessary (reverse coded); } \\
\text { (h) There are many different ways in which this activity can be conducted (reverse } \\
\text { coded); } \\
\text { (i) At the time of contracting for this activity, only a few core aspects of the prod- } \\
\text { uct or service were defined but not in any detail all specifications of the product or } \\
\text { service, technical details or deadlines (reverse coded). }\end{array}$ & \\
\hline \multicolumn{3}{|l|}{$\begin{array}{l}\text { Specific invest- } \\
\text { ments }\end{array}$} \\
\hline $\begin{array}{l}\text { Cronbach's } \alpha 0.87 \\
F=68.502\end{array}$ & $\begin{array}{l}\text { (a) This activity is conducted by means of resources (e.g. materials, machines, } \\
\text { technical equipment, hard- or software) that are specifically designed for our com- } \\
\text { pany or this project; } \\
\text { (b) With regard to this activity, the use of standard, common resources would lead } \\
\text { to sub-optimal results (e.g. lower productivity or quality, longer project duration); } \\
\text { (c) This activity requires specific capabilities and/or know-how that are not com- } \\
\text { mon in the industry; } \\
\text { (d) The provider of this activity to a larger extent adapted her operations, produc- } \\
\text { tion processes and/or procedures to the specific requirements of the project; } \\
\text { (e) Other producers would need some time before they would be able to conduct } \\
\text { this activity with the same effectiveness; } \\
\text { (f) When producing the good or service, the parties involved made significant mu- } \\
\text { tual adaptations of their internal processes and procedures; } \\
\text { (g) A different provider of this product or service would need considerable time to } \\
\text { be able to adapt to the internal processes and procedures of this project; } \\
\text { (h) For producing this product or service, it was necessary to purchase additional } \\
\text { resources and/or hire additional employees. }\end{array}$ & $\begin{array}{l}\text { 6-point Likert scale ranging from (1) } \\
\text { fully disagree - (6) fully agree }\end{array}$ \\
\hline
\end{tabular}




\begin{tabular}{|c|c|c|}
\hline \multicolumn{3}{|c|}{ DESCRIPTIVE VARIABLES } \\
\hline $\begin{array}{l}\text { Transacting par- } \\
\text { ties belong to } \\
\text { same firm }\end{array}$ & Does the supplier belong to your regional organization or firm? & $\begin{array}{l}\text { Dummy } \\
\text { 1: no 2: yes }\end{array}$ \\
\hline $\begin{array}{l}\text { Satisfaction with } \\
\text { governance of the } \\
\text { transaction } \\
\text { Cronbach's } \alpha \\
0.91 \\
\mathrm{~F}=9.413\end{array}$ & $\begin{array}{l}\text { (a) For this activity, how satisfied are you with regard to its cost? } \\
\text { (b) For this activity, how satisfied are you with regard to its quality? } \\
\text { (c) For this activity, how satisfied are you with regard to the bargaining cost in- } \\
\text { curred? } \\
\text { (d) For this activity, how satisfied are you with regard to its controllability? } \\
\text { (e) For this activity, how satisfied are you with regard to the adaptability to chang- } \\
\text { ing conditions? } \\
\text { (f) For this activity, how satisfied are you with regard to having achieving reliable } \\
\text { access to resources? } \\
\text { (g) For this activity, how satisfied are you with regard to the protection of invest- } \\
\text { ments and/or know how? } \\
\text { (h) For this activity, how satisfied are you with regard to the development of know } \\
\text { how? }\end{array}$ & $\begin{array}{l}\text { 5-point Likert scale ranging from (1) } \\
\text { very unsatisfied - (5) very satisfied. }\end{array}$ \\
\hline $\begin{array}{l}\text { Transaction vol- } \\
\text { ume }\end{array}$ & Monetary value of the transaction & \\
\hline Project duration & Duration of the project in months & \\
\hline $\begin{array}{l}\text { Task complexity } \\
\text { Cronbach's } \alpha 0.81 \\
\mathrm{~F}=4.327\end{array}$ & $\begin{array}{l}\text { (a) The execution of this task requires much experience and practical knowhow } \\
\text { that is difficult to encode in general process descriptions. } \\
\text { (b) The production process for this task is based on relatively complex proce- } \\
\text { dures/technologies and requires a variety of capabilities of production personnel. } \\
\text { (c) The execution of this task requires exact timely and substantive coordination of } \\
\text { different persons/experts. }\end{array}$ & $\begin{array}{l}\text { 6-point Likert scale ranging from (1) } \\
\text { fully agree - (6) fully disagree (re- } \\
\text { verse coded) }\end{array}$ \\
\hline $\begin{array}{l}\text { Past collabora- } \\
\text { tion }\end{array}$ & $\begin{array}{l}\text { (a) How often has your organization / firm collaborated with this supplier in the } \\
\text { past? }\end{array}$ & $\begin{array}{l}\text { 6-point Likert scale } \\
\text { (1) never - (6) very frequently }\end{array}$ \\
\hline $\begin{array}{l}\text { Industry norms } \\
\text { Cronbach's } \alpha 0.87 \\
\mathrm{~F}=0.895\end{array}$ & $\begin{array}{l}\text { (a) The way in which this product or service is to be produced is heavily regulated } \\
\text { by (voluntarily applied) industry norms (e.g. ISO norms). } \\
\text { (b) The assessment of whether or not the finished product or service is acceptable }\end{array}$ & $\begin{array}{l}\text { 6-point Likert scale ranging from } \\
\text { (1) fully disagree - (6) fully agree }\end{array}$ \\
\hline
\end{tabular}




\begin{tabular}{|l|l|l|}
\hline & to a large extent is based on (voluntarily applied) industry norms (e.g. ISO norms). & \\
\hline Trust & We rely on this supplier performing appropriately and correctly, even in the ab- & 6-point Likert scale ranging from (1) \\
Cronbach's $\alpha 0.84$ & sence of formal controls, with regard to: & \\
F=70.143 & $\begin{array}{l}\text { (a) the selection of task inputs, } \\
\text { (b) the quantity and quality of task performance, } \\
\text { (c) meeting deadlines. }\end{array}$ & \\
\hline
\end{tabular}




\section{References}

Albers, S., Wohlgezogen, F., \& Zajac, E. J. 2013. Strategic alliance structures: an organization design perspective. Journal of Management.

Anderson, S. W., \& Dekker, H. C. 2005. Management control for market transactions: the relation between transaction characteristics, incomplete contract design, and subsequent performance. Management Science, 51(12): 1734-1752.

Argyres, N., \& Mayer, K. J. 2007. Contract design as a firm capability: An integration of learning and transaction cost perspectives. Academy of Management Review, 32(4): 1060-1077.

Argyres, N. S., Bercovitz, J., \& Mayer, K. J. 2007. Complementarity and evolution of contractual provisions: An empirical study of IT services contracts. Organization Science, 18(1): 3-19.

Baker, G. P., Gibbons, R., \& Murphy, K. J. 2008. Strategic alliances: Bridges between "islands of conscious power". Journal of the Japanese and International Economies, 22(2): 146-163.

Bauindustrie, H. d. D. 2009. Industry statistics. http://www.bauindustrie.de/zahlenfakten/statistik/.

Bensaou, M., \& Venkatraman, N. 1995. Configurations of interorganizational relationships: A comparison between U.S. and Japanese automakers. Management Science, 41(9): 1471-1492.

Biggart, N. W., \& Delbridge, R. 2004. Systems of exchange. Academy of Management Review, 29(1): 28-49.

Blois, K. J. 1972. Vertical quasi-integration. Journal of Industrial Economics, 20(3): 253-272.

Borys, B., \& Jemison, D. B. 1989. Hybrid arrangements as strategic alliances: theoretical issues in organizational combinations. Academy of Management Review, 14(2): 234-249.

Bradach, J. L., \& Eccles, R. G. 1989. Price, authority, and trust: from ideal types to plural forms. Annual Review of Sociology, 15(1): 97-118.

Bresnen, M., Edelman, L., Newell, S., Scarbrough, H., \& Swan, J. 2003. Social practices and the management of knowledge in project environments. International Journal of Project Management, 21(3): 157-166.

Bruce, K., \& Jordan, J. 2007. Between markets and hierarchies: Towards a better taxonomy of hybrid organizational forms? Technology Analysis \& Strategic Management, 19(1): 7-16.

Buvik, A. 2002. Hybrid governance and governance performance in industrial purchasing relationships. Scandinavian Journal of Management, 18(4): 567.

Cai, S. H., Yang, Z. L., \& Hu, Z. H. 2009. Exploring the governance mechanisms of quasiintegration in buyer-supplier relationships. Journal of Business Research, 62(6): 660-666. 
Cannon, J. P., Achrol, R. S., \& Gundlach, G. T. 2000. Contracts, norms, and plural form governance. Journal of the Academy of Marketing Science, 28(2): 180-194.

Cannon, J. P., \& Perreault Jr, W. D. 1999. Buyer-seller relationships in business markets. Journal of Marketing Research (JMR), 36(4): 439-460.

Carson, S. J., Madhok, A., \& Wu, T. 2006. Uncertainty, opportunism, and governance: the effects of volatility and ambiguity on formal and relational contracting. Academy of Management Journal, 49(5): 1058-1077.

Casciaro, T. 2003. Determinants of governance structure in alliances: the role of strategic, task and partner uncertainties. Industrial and Corporate Change, 12(6): 1223-1251.

Chang, S.-J., Chung, J., \& Moon, J. J. 2013. When do wholly owned subsidiaries perform better than joint ventures? Strategic Management Journal, 34(3): 317-337.

Chiles, T. H., \& McMackin, J. F. 1996. Integrating variable risk preferences, trust, and transaction cost economics. Academy of Management Review, 21(1): 73-99.

Coleman, J. S. 1990. Foundations of Social Theory. Cambridge, MA: Harvard University Press.

Costantino, N., \& Pietroforte, R. 2002. Subcontracting practices in USA homebuilding: An empirical verification of Eccles's findings 20 years later. European Journal of Purchasing \& Supply Management, 8: 15-23.

Crook, T. R., Combs, J. G., Ketchen, D. J., \& Aguinis, H. 2013. Organizing around transaction costs: What have we learned and where do we go from here? The Academy of Management Perspectives, 27(1): 63-79.

Cropper, S., Ebers, M., Huxham, C., \& Ring, P. S. (Eds.). 2008. The Oxford Handbook of InterOrganizational Relations. Oxford: Oxford University Press.

Dacin, T. M., Ventresca, M. J., \& Beal, B. D. 1999. The embeddedness of organizations: dialogue and directions. Journal of Management, 25(3): 317-356.

Dekker, H. C. 2004. Control of inter-organizational relationships: Evidence on appropriation concerns and coordination requirements. Accounting, Organizations \& Society, 29(1): 27-49.

Dekker, H. C., \& Van den Abbeele, A. 2010. Organizational learning and interfirm control: the effects of partner search and prior exchange experiences. Organization Science, 21(6): 12331250 .

Dyer, J. H. 1997. Effective interfirm collaboration: how firms minimize transaction costs and maximize transaction value. Strategic Management Journal, 18(7): 535-556.

Dyer, J. H., \& Chu, W. J. 2003. The role of trustworthiness in reducing transaction costs and improving performance: Empirical evidence from the United States, Japan, and Korea. Organization Science, 14(1): 57-68. 
Dyer, J. H., \& Nobeoka, K. 2000. Creating and managing a high-performance knowledge-sharing network: The Toyota case. Strategic Management Journal, 21(3): 345-367.

Dyer, J. H., \& Singh, H. 1998. The relational view: Cooperative strategy and sources of interorganizational competitive advantage. Academy of Management Review, 23(4): 660-679.

Eccles, R. G. 1981. The quasifirm in the construction industry. Journal of Economic Behavior \& Organization, 2(4): 335-357.

Eisenhardt, K. M. 1985. Control: organizational and economic approaches. Management Science, 31(2): 134-149.

Eisenhardt, K. M. 1988. Agency- and institutional-theory explanations: The case of retail sales compensation. Academy of Management Journal, 31(3): 488-511.

Eisenhardt, K. M. 1989. Agency theory: An assessment and review. Academy of Management Review, 14(1): 57-74.

Fama, E. F., \& Jensen, M. C. 1983. Separation of Ownership and Control. Journal of Law and Economics, 26(2): 301-325.

Foss, N. J. 2003. Selective intervention and internal hybrids: interpreting and learning from the rise and decline of the Oticon spaghetti organization. Organization Science, 14(3): 331-349.

Gann, D. M., \& Salter, A. J. 2000. Innovation in project-based, service-enhanced firms: The construction of complex products and systems. Research Policy, 29(7/8): 955-972.

Garcia-Pont, C., \& Nohria, N. 2002. Local versus global mimetism: the dynamics of alliance formation in the automobile industry. Strategic Management Journal, 23(4): 307-321.

Geyskens, I., Steenkamp, J. B. E. M., \& Kumar, N. 2006. Make, buy, or ally: A transaction cost theory meta-analysis. Academy of Management Journal, 49(3): 519-543.

Ghoshal, S., \& Moran, P. 1996. Bad for practice: A critique of the transaction cost theory. Academy of Management Review, 21(1): 13-47.

Gibbons, R. 2005. Four formal(izable) theories of the firm? Journal of Economic Behavior \& Organization, 58(2): 200-245.

González-Díaz, M., Arruñada, B., \& Fernández, A. 2000. Causes of subcontracting: evidence from panel data on construction firms. Journal of Economic Behavior \& Organization, 42(2): 167-187.

Grandori, A. 1997. An organizational assessment of interfirm coordination modes. Organization Studies, 18(6): 897-925.

Granovetter, M. 1985. Economic action and social structure: The problem of embeddedness. American Journal of Sociology, 91(3): 481-510. 
Greenwood, R., Oliver, C., Sahlin-Andersson, K., \& Suddaby, R. (Eds.). 2007. Handbook of Organizational Institutionalism. Thousand Oaks: Sage.

Gulati, R. 1995. Does familiarity breed trust - the implications of repeated ties for contractual choice in alliances. Academy of Management Journal, 38(1): 85-112.

Gulati, R., Lawrence, P. R., \& Puranam, P. 2005. Adaptation in vertical relationships: beyond incentive conflict. Strategic Management Journal, 26(5): 415-440.

Gulati, R., \& Nickerson, J. A. 2008. Interorganizational trust, governance choice, and exchange performance. Organization Science, 19(5): 688-708.

Gulati, R., \& Singh, H. 1998. The architecture of cooperation: managing coordination costs and appropriation concerns in strategic alliances. Administrative Science Quarterly, 43(4): 781-814.

Hagenaars, J. A., \& McCutcheon, A. L. 2002. Applied Latent Class Analysis. Cambridge: Cambridge University Press.

Hart, O., \& Moore, J. 1999. Foundations of incomplete contracts. Review of Economic Studies, 66(226): 115-138.

Heide, J. B., \& John, G. 1990. Alliances in industrial purchasing: the determinants of joint action in buyer-supplier relationships. Journal of Marketing Research, 27(1): 24-36.

Helper, S., MacDuffie, J. P., \& Sabel, C. 2000. Pragmatic collaborations: Advancing knowledge while controlling opportunism. Industrial and Corporate Change, 9(3): 443-488.

Hennart, J.-F. 1993. Explaining the swollen middle: Why most transactions are a mix of "market" and "hierarchy". Organization Science, 4(4): 529-547.

Hennart, J. F. 1988. A transaction costs theory of equity joint ventures. Strategic Management Journal, 9(4): 361-374.

Hill, C. W. L. 1990. Cooperation, opportunism, and the invisible hand: implications for transaction cost theory. Academy of Management Review, 15(3): 500-513.

Hodgson, G. M. 2002. The legal nature of the firm and the myth of the firm-market hybrid. International Journal of the Economics of Business, 9(1): 37-60.

Hoetker, G., \& Mellewigt, T. 2009. Choice and performance of governance mechanisms: matching alliance governance to asset type. Strategic Management Journal, 30(10): 1025-1044.

Jensen, M. C., \& Meckling, W. 1976. Theory of the firm: Managerial behavior, agency costs, and ownership structure. Journal of Financial Economics, 3 305-360.

John, G., \& Reve, T. 1982. The reliability and validity of key informant data from dyadic relationships in marketing channels. Journal of Marketing Research, 19(4): 517-524. 
John, G., \& Weitz, B. A. 1988. Forward integration into distribution: an empirical test of transaction cost analysis. Journal of Law, Economics and Organization, 4(2): 337-355.

Jolink, A., \& Niesten, E. 2012. Recent qualitative advances on hybrid organizations: Taking stock, looking ahead. Scandinavian Journal of Management, 28(2): 149-161.

Jones, C., Hesterly, W. S., \& Borgatti, S. P. 1997. A general theory of network governance: Exchange conditions and social mechanisms. Academy of Management Review, 22(4): 911-945.

Judge, W. Q., \& Dooley, R. 2006. Strategic alliance outcomes: a transaction-cost economics perspective. British Journal of Management, 17(1): 23-37.

Kadefors, A. 2005. Fairness in interorganizational project relations: norms and strategies. Construction Management \& Economics, 23(8): 871-878.

Kalnins, A., \& Mayer, K. J. 2004. Relationships and hybrid contracts: an analysis of contract choice in information technology. Journal of Law, Economics \& Organization, 20(1): 207-229.

Kasch, S., \& Dowling, M. 2008. Commercialization strategies of young biotechnology firms: An empirical analysis of the U.S. industry. Research Policy, 37(10): 1765-1777.

Klein Woolthuis, R., Hillebrand, B., \& Nooteboom, B. 2005. Trust, contract and relationship development. Organization Studies, 26(6): 813-840.

Lai, L. W. C. 2000. The Coasian market-firm dichotomy and subcontracting in the construction industry. Construction Management \& Economics, 18(3): 355-362.

Lin, C. P., \& Lin, H. M. 2010. Maker-buyer strategic alliances: an integrated framework. Journal of Business \& Industrial Marketing, 25(1-2): 43-56.

Lui, S. S., \& Ngo, H.-Y. 2004. The role of trust and contractual safeguards on cooperation in non-equity alliances. Journal of Management, 30(4): 471-485.

Lui, S. S., \& Ngo, H.-Y. 2005. An action pattern model of inter-firm cooperation. Journal of Management Studies, 42(6): 1123-1153.

Luo, Y. 2002. Contract, cooperation, and performance in international joint ventures. Strategic Management Journal, 23(10): 903-919.

Macaulay, S. 1963. Non-contractual relations in business: a preliminary study. American Sociological Review, 28(1): 55-67.

Magidson, J., \& Vermunt, J. K. 2004. Latent class models. In D. Kaplan (Ed.), The Sage Handbook of Quantitative Methodology for the Social Sciences: 175-192. Thousand Oaks, CA: Sage Publications, Inc.

Makadok, R., \& Coff, R. 2009. Both market and hierarchy: an incentive-system theory of hybrid governance forms. Academy of Management Review, 34(2): 297-319. 
Mantere, S., \& Ketokivi, M. 2013. Reasoning in Organization Science. Academy of Management Review, 38(1): 70-89.

Masten, S. E. (Ed.). 1996. Case Studies in Contracting and Organization. New York, London: Oxford University Press.

Mayer, K. J., \& Argyres, N. S. 2004. Learning to contract: Evidence from the personal computer industry. Organization Science, 15(4): 394-410.

Mayer, K. J., \& Nickerson, J. A. 2005. Antecedents and performance implications of contracting for knowledge workers: evidence from information technology services. Organization Science, 16(3): 225-242.

Mayer, K. J., \& Salomon, R. M. 2006. Capabilities, contractual hazards, and governance: Integrating resource-based and transaction cost perspectives. Academy of Management Journal, 49(5): 942-959.

Mayer, K. J., \& Teece, D. J. 2008. Unpacking strategic alliances: The structure and purpose of alliance versus supplier relationships. Journal of Economic Behavior \& Organization, 66(1): 106127.

McEvily, B., Perrone, V., \& Zaheer, A. 2003. Trust as an organizing principle. Organization Science, 14(1): 91-103.

Ménard, C. 1996. On clusters, hybrids and other strange forms: the case of the French poultry industry. Journal of Institutional and Theoretical Economics JITE, 152(1): 154-183.

Ménard, C. 2004. The economics of hybrid organizations. Journal of Institutional and Theoretical Economics JITE, 160(3): 345-376.

Ménard, C. 2012. Hybrid modes of organization. Alliances, joint ventures, networks, and other 'strange' animals In R. Gibbons and J. Roberts (Eds.), The Handbook of Organizational Economics: 1066-1108. Princeton: Princeton University Press.

Mesquita, L. F., \& Brush, T. H. 2008. Untangling safeguard and production coordination effects in long-term buyer-supplier relationships. Academy of Management Journal, 51(4): 785-807.

Meyer, A. D., Tsui, A. S., \& Hinings, C. R. 1993. Configurational approaches to organizational analysis. Academy of Management Journal, 36(6): 1175-1195.

Milgrom, P., \& Roberts, J. 1992. Economics, Organization and Management. Englewood Cliffs, NJ: Prentice Hall.

Nahapiet, J., \& Ghoshal, S. 1998. Social capital, intellectual capital, and the organizational advantage. Academy of Management Review, 23(2): 242-266.

Ngowi, A. B. 2007. The role of trustworthiness in the formation and governance of construction alliances. Building and Environment, 42(4): 1828-1835. 
Noorderhaven, N. G. 1995. Transaction, interaction, institutionalization: Toward a dynamic theory of hybrid governance. Scandinavian Journal of Management, 11(1): 43-55.

Nooteboom, B., Berger, H., \& Noorderhaven, N. G. 1997. Effects of trust and governance on relational risk. Academy of Management Journal, 40(2): 308-338.

Oerlemans, L. A. G., \& Meeus, M. T. H. 2001. R\&D cooperation in a transaction cost perspective. Review of Industrial Organization, 18(1): 77-90.

Oliver, A. L., \& Ebers, M. 1998. Networking network studies: An analysis of conceptual configurations in the study of inter-organizational relationships. Organization Studies, 19(4): 549-583.

Oliver, C. 1996. The institutional embeddedness of economic activity. In J. A. C. Baum and J. E. Dutton (Eds.), Advances in Strategic Management: 163-186. Greenwich, CT: JAI Press.

Ouchi, W. G. 1979. A conceptual framework for the design of organizational control mechanisms. Management Science, 25(9): 833-848.

Oxley, J. E. 1999. Institutional environment and the mechanisms of governance: the impact of intellectual property protection on the structure of inter-firm alliances. Journal of Economic Behavior \& Organization, 38(3): 283-309.

Parkhe, A. 1993. Strategic alliance structuring: a game theoretic and transaction cost examination of interfirm cooperation. Academy of Management Journal, 36(4): 794-829.

Parmigiani, A., \& Rivera-Santos, M. 2011. Clearing a path through the forest: A meta-review of interorganizational relationships. Journal of Management, 37(4): 1108-1136.

Pfeffer, J., \& Nowak, P. 1976. Joint ventures and interorganizational interdependence. Administrative Science Quarterly, 21(3): 398-418.

Pfeffer, J., \& Salancik, G. R. 2003. The External Control of Organizations: A Resource Dependence Perspective (2 ed.). Stanford, CA: Stanford University Press.

Podsakoff, P. M., MacKenzie, S. B., Jeong-Yeon, L., \& Podsakoff, N. P. 2003. Common method biases in behavioral research: A critical review of the literature and recommended remedies.

Journal of Applied Psychology, 88(5): 879-903.

Podsakoff, P. M., \& Organ, D. W. 1986. Self-reports in organizational research: Problems and prospects. Journal of Management, 12(4): 531-544.

Polidoro, F., Ahuja, G., \& Mitchell, W. 2011. When the social structure overshadows competitive incentives: the effects of network embeddedness on joint venture dissolution. Academy of Management Journal, 54(1): 203-223.

Poppo, L., \& Zenger, T. 2002. Do formal contracts and relational governance function as substitutes or complements? Strategic Management Journal, 23(8): 707-725. 
Poppo, L., Zhou, K. Z., \& Ryu, S. 2008. Alternative origins to interorganizational trust: An interdependence perspective on the shadow of the past and the shadow of the future.

Organization Science, 19(1): 39-55.

Powell, W. W. 1987. Hybrid organizational arrangements: New form or transitional development? California Management Review, 30(1): 67-87.

Powell, W. W. 1990. Neither market nor hierarchy: network form of organization. Research in Organizational Behavior, 12: 295-336.

Reuer, J., \& Zollo, M. 2000. Managing governance adaptations in strategic alliances. European Management Journal, 18(2): 164.

Reuer, J. J., \& Ariño, A. 2007. Strategic alliance contracts: Dimensions and determinants of contractual complexity. Strategic Management Journal, 28(3): 313-330.

Rindfleisch, A., Antia, K., Bercovitz, J., Brown, J. R., Cannon, J., Carson, S. J., Ghosh, M., Helper, S., Robertson, D. C., \& Wathne, K. H. 2010. Transaction costs, opportunism, and governance: contextual considerations and future research opportunities. Marketing Letters, 21(3): 211-222.

Ryu, S., Min, S., \& Zushi, N. 2008. The moderating role of trust in manufacturer-supplier relationships. Journal of Business \& Industrial Marketing, 23(1): 48-58.

Schoorman, F. D., Mayer, R. C., \& Davis, J. H. 2007. An integrative model of organizational trust: Past, present, and future. Academy of Management Review, 32(2): 344-354.

Scott, W. R. 2001. Institutions and Organizations (2 ed.). Thousand Oaks, CA: Sage.

Short, J. C., Payne, G. T., \& Ketchen, D. J., Jr. 2008. Research on organizational configurations: Past accomplishments and future challenges. Journal of Management, 34(6): 1053-1079.

Simonin, B. L. 1999. Ambiguity and the process of knowledge transfer in strategic alliances. Strategic Management Journal, 20(7): 595-623.

Söderlund, J. 2000. Temporary organizing - Characteristics and control forms. In R. A. Lundin and F. Hartman (Eds.), Projects as business constituents and guiding motives: 61-74. Boston: Kluwer Academic Publishers.

Swedberg, R. 2003. Principles of Economic Sociology. Princeton, NJ: Princeton University Press.

Sydow, J., Lindkvist, L., \& DeFillippi, R. 2004. Project-based organizations, embeddedness and repositories of knowledge: Editorial. Organization Studies, 25(9): 1475-1489.

Tuuli, M. M., Rowlinson, S., \& Tas Yong, K. O. H. 2010. Control modes and mechanisms in construction project teams: drivers and consequences. Construction Management \& Economics, 28(5): 451-465. 
Uzzi, B. 1996. The sources and consequences of embeddedness for the economic performance of organizations: The network effect. American Sociological Review, 61(4): 674-498.

Uzzi, B. 1997. Social structure and competition in interfirm networks: The paradox of embeddedness. Administrative Science Quarterly, 42(1): 35-67.

Uzzi, B. 1999. Embeddedness in the making of financial capital: How social relations and networks benefit firms seeking financing. American Sociological Review, 64(4): 481-505.

Vermunt, J. K., \& Magidson, J. 2003. Latent class models for classification. Computational Statistics and Data Analysis, 41(3-4): 531-537.

Walker, G., \& Poppo, L. 1991. Profit centers, single-source suppliers, and transaction costs. Administrative Science Quarterly, 36(1): 66-87.

Wathne, K. H., \& Heide, J. B. 2004. Relationship governance in a supply chain network. Journal of Marketing, 68(1): 73-89.

White, S. 2005. Cooperation costs, governance choice and alliance evolution. Journal of Management Studies, 42(7): 1383-1412.

White, S., \& Lui, S. S.-Y. 2005. Distinguishing costs of cooperation and control in alliances. Strategic Management Journal, 26(10): 913-932.

Williamson, O. E. 1985. The Economic Institutions of Capitalism. New York: Free Press.

Williamson, O. E. 1991. Comparative economic organization: the analysis of discrete structural alternatives. Administrative Science Quarterly, 36(2): 269-296.

Williamson, O. E. 2008. Outsourcing: transaction cost economics and supply chain management. Journal of Supply Chain Management, 44(2): 5-16.

Winch, G. 1989. The construction firm and the construction project: A transaction cost approach. Construction Management \& Economics, 7(4): 331-345.

Winch, G. M. 2001. Governing the project process: a conceptual framework. Construction Management \& Economics, 19(8): 799-808.

Zenger, T. R. 2002. Crafting internal hybrids: Complementarities, common change initiatives, and the team-based organization. International Journal of the Economics of Business, 9(1): 7995.

Zenger, T. R., \& Hesterly, W. S. 1997. The dissaggregation of corporations: selective intervention, high-powered incentives, and molecular units. Organization Science, 8(3): 209-222.

Zheng, J., Roehrich, J. K., \& Lewis, M. A. 2008. The dynamics of contractual and relational governance: evidence from long-term public-private procurement arrangements. Journal of Purchasing and Supply Management, 14(1): 43-54. 
Zollo, M., Reuer, J. J., \& Singh, H. 2002. Interorganizational routines and performance in strategic alliances. Organization Science, 13(6): 701-713. 